Portland State University

PDXScholar

1989

\title{
Spanish expeditions to the Northwest Coast during the Bucareli administration, 1771-1779
}

Mark Cronlund Anderson

Portland State University

Follow this and additional works at: https://pdxscholar.library.pdx.edu/open_access_etds

Part of the History Commons

Let us know how access to this document benefits you.

\section{Recommended Citation}

Anderson, Mark Cronlund, "Spanish expeditions to the Northwest Coast during the Bucareli administration, 1771-1779" (1989). Dissertations and Theses. Paper 3895.

https://doi.org/10.15760/etd.5765

This Thesis is brought to you for free and open access. It has been accepted for inclusion in Dissertations and Theses by an authorized administrator of PDXScholar. Please contact us if we can make this document more accessible: pdxscholar@pdx.edu. 
AN ABSTRACT OF THE THESIS OF Mart: Cranlund Anderson far the Master of Arts in Histary presented June E, 1989.

Title: Spanish Expeditians to the Northwest Coast During the Eucare]i Administration, 1771-1779.

APPROVED EY THE MEMEERS OF THE THESIS COMMITTEE:
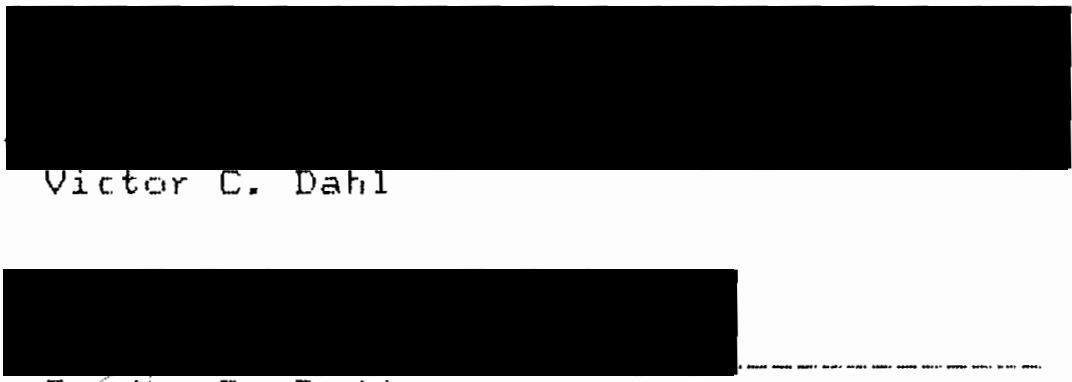

Getron B. Dodds

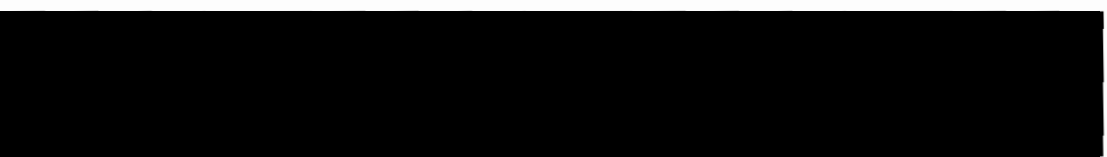

Charles Rn White

Na discreet study of the Sperish voyages of discovery and ewploration to the northwest coast of North America during the 1770 s has been published in English. The purpose of this thesis is to examine the spanish expeditions of 1.774, 1.775, and 1.779 , directed by New Spain's Viceray Antomia Maria Bucareli y Ursua $01771-17791$. 
Mast immediately, the 1770"s expeditions sought to establish a legally temable Spanish presence an the northwest coast to trwart perceived foreign--especialiy Russian and Eritish--designs. Viceroy Eucareli's detailed instructians reflected these concerns. The mariners-m Jun Perez, Bruna de Hezeta, Juan Francisca de 1 a Bodega y Quadra, and Igracio Arteaga-were successful in fulfilling their arders to varying degrees and for different reasoris, histgrians have argued.

Ey examining the extant 1 iterature an the earlier-sixteenth and early seventeenth centuries--voyages ta the northwest littoral, one can delineate other, culturally determined continuities between the impetuses berind the earjy voyages and those of the 1770 s. Curigusiy, this 1. intage has gome unnoticed by tidstorians.

The Bucareli-directed expeditions have been examined by scholars tangentially, as parts of other studies. The body of literature is not immodest; the conclusions reached are mixed. Few af the studies rely on primary research, and mamy eimply rejay the "facts" without syntheses. The more direct investigatians, typically focused on the $1790 \%$ Nowtia Sound controversy which brought Spain and Britain to the brink of war, fashian narrative structures into which the Bucareli-directed expeditiars serve as "setting." Fortunately, the respective ships, loge exist in tranelated form. 
Research for this thesis was canducted at the Portland State University Library, the Multnomah County Library, the Gregon Historical Society Library, and the Provincial Archives in Victoria, British Columbia. 
SPANISH EXPEDITIONS TO THE NORTHWEST COAST DURING THE

EUCAREL. J. ADMINJSTRATION, $1771-1779$

by

MARK: CRONLUND ANDERSON

A thesis submitted in partial fulfillment of the requirements for the degree of

MASTER OF ARTS

in

HISTURY

Fortland State University

$190 \%$ 
TO THE OFFICE OF GRADUATE STUDI.ES:

The members of the Committee approve the thesis of Mart:

Cronlund Anderson presented June E, 1989.
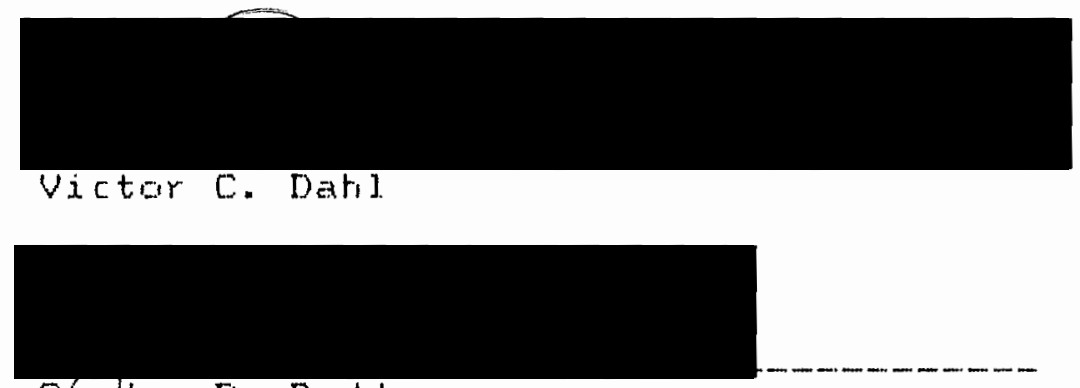

GQYOAn B. DoddE

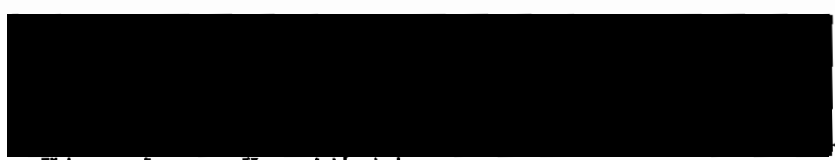

Chardes R. White

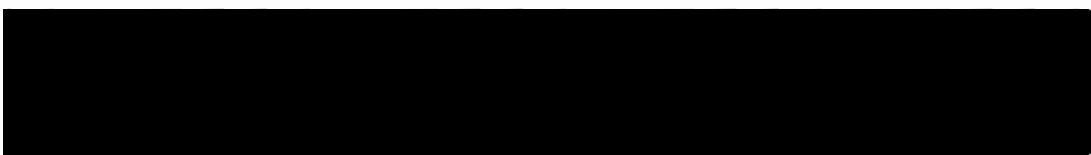

Carl Abtott
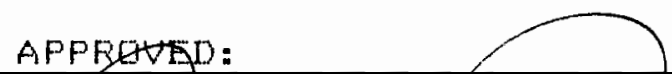

Fernard V. Burle, Chair, Department Gf Histary

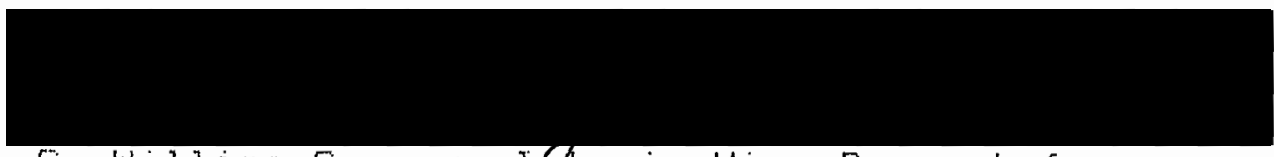

C. William Savery, IRAerin Vice Provost far

Graduate Studies and Resedrch 


\section{ACKNOWLEDGEMENTS}

Professor Datil an a number of accasions reminded me, paraphrasing Herbert Eugene Bglton, as I reca11, that completing a project of this sort required sitting down and not getting up until one rad put a good shime on the seat of ane's pants. He was right. I would lite ta thank him far his wise, considered counsel, tis good humor, and tis no monsense editing.

And Carmen, well, J thant her for everything. 
TABLE OF CONTENTS

PAGE

ACKNOWLEDEEMENTS. ....................... ii

CHAPTER

I PRELUde to THE spanish LAKE $\ldots \ldots \ldots \ldots \ldots \ldots . . . . .1$

Early voyages................... z

The Manila Galleon................ 8

Search for the Strait of Anian........ 9

Colanial Society in New Spain......... 15

Hapsburg Rule.................... 19

The War of the Spanish succession...... 23

IJ. RETURN TO THE NORTHWEST COAST........... 25

Eourbon kings................... 26

Visitor-General Jose de Galvez........ 30

The Naval Station at San Blas......... 3

North to Manterey................ 38

Eeyond California................. 40

Apocryphal Voyages................ 40

I I UNDER GUCAREL'S DIRECTION. . . . . . . . . 45

The Juan Perez Expedition........... 48

The Hezeta Expeditian.............. 53

Arteaga and Eodega............... 58

IV MEASURINE SUCCESE................ 
Whither Juan Perez................. 64

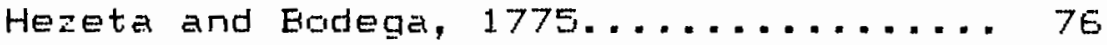
Arteaga and Bodega, $1779 . . . . . . . . .79$ One, Two, Three.................... 80

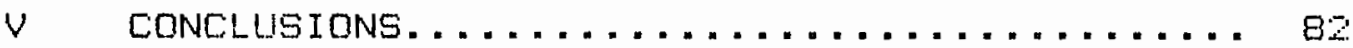

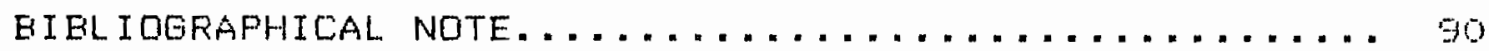

REFERENCES.................................... 94 


\section{CHAPTER I}

\section{PRELUDE TO THE SPANISH LAKE}

The purpose of this thesis is to examine the Spanish expeditions to the northwest coast of North America that sailed during Viceroy Antonio Maria Eucareli y Ursua's administration, 1771-1779. In order to achieve this aim several factors, apart from the voyages per se, must first be addressed. Chapter I explores the Iinkage that existed between the initial expeditions to the northwest littoral in the sixteenth and early seventeenth centuries and those under Bucareli's direction in the 1770's. This chapter also examines the sacia-cultural context in which the early northward thrust accurred, that is, a purview of the salient elements of Hapsburg rule of the Spanish empire.

Chapter I introduces the bey players promoting the 1770's expeditions, Viceroy Bucareli and Visitador Jose de Galvez. These two prominent figures require placement within the context of the Enlightenment, of which they were a part and product; thus, the transition between Hapsburg and Bourbon rule of Spain's empire is fundamental, as are the steps Eucareli and Galvez took: with regard to the northwest coast. The final elements of the socia-cultural lintage tying the Eucareli-directed expedidtions to the sixteenth and seventeenth centuries were three apocryphal forays into 
the Northwest Passage, reputedly sailed between 1588 and 1640.

The courses of the expeditions--Juan Perez in 177\%, Bruno de Hezeta and Juan Francisco de la Badega y Quadra in 1775, and Ignacio Arteaga and Elodega y Quadra in 1779--and what they accomplished, are traced in Chapter II I. These narratives require same explanatian of Eucareli's detailed instructions far the sailars, especially with regard ta possessian-tating.

The penultimate chapter of this study examines how histarians writing in English have evaluated the expeditions, and why. Eodega, for example, has been praised enthusiastically by virtually ail marthwest scholars, while Perez has been both vilified and lasded. Following Chapter IV a series af abservations conclude the text of this wort.

\section{FARLY VOYAGES}

Spain's interest in the northwest coast af North America which spanned from the sixteenth through eighteenth centuries, has received considerable notice by histarians writing in the English language. However, the pivotal first voyages of the eighteenth century that returned spanish influence to the region after almost two centuries of neglect sailed during the viceregal administration of Antonio Eucareli (1771-1779), and have curiausly remained relatively unstudied ass a discreet tapic of inquiry. 
How histary has treated the mariners of the Eucareli

years is of especial importance because Spanish territorial claims to the northwest coast that drew the Iberian mation to the brink of war with Eritain in the early $1790^{\prime} 5$ in large part derived from the accomplishments of these expeditians. Spain's backing away from its claims to absolute sovereignty to avoid conflict with its lang-time rival effectively signaled the end of Spanish efforts to secure the regian.

History has generally measured the successes af the voyages in the cantext of the spanish attempt to protect the coast and the hinterland it sheltered from foreign encroachments. The more general impetuses behind Spain's northward thrust in the $1770^{\circ} 5$ reached back: hundreds of years to the essential reasans that led spain to discover and conquer the New World, but for the most part they have not been discussed in the literature. Yet the general causal factors engendering the Eucareli expeditions largely mirrored those behind the earliest voyages of the late sixteentr and early seventeenth centuries.

The story of the Spanish presence on the Pacific coast of Narth America logically begins with its discovery by Vasca Nunez de Balboa who sighted the world's largest body af water from its western shares in 1513. Ealbaa, like Hernan Cortes and Francisco Pizarro a native of the Spanist province of Extremadura, had only recently united the failed colonies in Panama and northern Colombia (1509-1511) when 
tales of a land fabulgusly rict in gold reached tim. 1 A true conquistador Balboa was moved to lead an expedition across the isthmus where, he had been assured, he would encounter a great sea, beyond which to the south lay a land of riches (Peru).z of course, Balboa never arrived there; in fact, tis accomplistiment as being the first European to see the Pacific from its western share provaked the envy of Pedrarias Davila, his father-in-law and governor af the Panamanian isthmus, who ordered Balboa to be tried, condemned, and beheaded in 1519 .

After Hernan Cortes, first chief of the Conquest of Mexico, had largely subdued the Aztec confederacy in the 1520's, he turned his rapacious appetite to the Pacific coast. As de facto governor of New Spain lie outfitted several expeditions to reconnoiter northerly waters. In 1532 native Americans on the Sinaloa coast massacred the first of these parties, led by Diego Hurtado de Mendoza. 9 A second expedition consisting of twa ships--the first of which

"turned back: befare accomplishing anything of importance",--mutinied and billed the captain af the latter

1 For the sake of clarity and readability all place names emplayed will those presently used.

a This point should properly stand as conjectural: the Indians often lied to the invaders with the hope that they would simply go away. See Clarence Haring, The spanish Empire in the America CNew Yort: Oxtord University Press, 1.947\%.

D Maurice G. Holmes, From Hew Spain by Sea to the Californias CGlendale: The Arthur H. Clarte Co., 1963) $57-$ 58. 
vessel. The voyage managed to continue under the capable fiand of its former pilat, Fortun Jimenez. Yet this exploration, like that of Hurtado de Mendoza, ended tragically when native Americans killed mast of its crew in the vicinity of La Paz, at the south end of the Baja peninsula. Mare impartantly, the survivors returned with fabricated stories of gold and pearls.5 Thus, in 1535 Cortes himself sailed north, landing near La Paz, only to shartly return to Mexico empty-handed. E This expeditian, mareaver, encountered considerable difficulty in actually reaching Eaja Califarnia: Z3 men died af starvatian.?

Meanwhile, other chimerical tales uf riches in distant lands fueled a predisposition amang circles in the viceregal capital, Mexica City, to substitute fantasy for reality. For example, rumors of the heralded metrapalis af cibola, one af seven such purported cities rich in gold, silver, and emeralds, encouraged Cortes to deploy triree subsequent expeditions up the coast. 9 In 1539 Francisco de Ullaa led the most noteworthy early expeditian ta the end af the Eay

4 Warren Cogt:, Flood Tide of Empire CNew Haven: Yale University Press, 1973 ? 2.

$=$ Cogt: 5 . $12-30$

- See Holmes's chapter, "To California with Cartes,"

7 Jotin W. Caughey, Cal ifommia (New Yorles Prentice-Hall, Inc., $1340 \% 53$.

- According to a legend, after the eighth century Moslem invasion of Iberia, seven Portuguese bishops fled to the west and founded the enchanted cities af Cibola. Faul Horgan, Conquistadors in North American History (New Yarl: Farrar, Straus and Company, 19Eכ): 115-1E. 
of Califarnia, thereby demonstrating the coastline's contiguity and that Baja California formed a penirisula. Dddly enough, rgyal officials and other explorers ignored this information, choosing instead to believe it was an island, until its 're-discovery', by Padre Eusebio Kino in 1701. And it was nat until 1746 that royal officials declared California no es isla pero es tierra firmes Additionally, Maurice Holmes maintains that Ulloa, after rounding Cabo San Lucas, sailed as far north as present-day San Diego. Warren Cont, among others, 10 tempers this claim in asserting the voyage passed no further than 30 degrees North latitude CSan Diego is located at about 32 degrees North). Writing in the late nineteenth century, Hubert Howe Eancroft in a seminal wort: largely stirugs off the voyage as alogether devoid of any substantive histarical importance, except with regard to the "forgotten" yet accurate discavery that Eaja California formed a peninsula, not an island. 11

- Irving B. Richman, Caljfornia Under spain and Mexiag (New Yort: Cogper Square Publishers, 1965) 59.

10. See Henry R. Wagner, Spanish voyages to the Northwest Coast of America in the Sixteenth Century isan Francisca: California Historical Society, 1929) 14. Holmes's calculation was clearly taten from the official journals of the voyage. Wagner's wort:, however, in the minds of virtually all authoritative recent accounts transcends the veracity of sixteenth century nautical instruments. It is somewhat surprising that Holmes chooses the original, given the quality of tis study and the stature of wagner's cartograptical corrections.

11 Hubert Howe Eancroft, History of the North Hexican States, XV (San Francisco, 188-) 79. 
The Seven Cities tales inspired Viceray Antonia de Mendozaz ta send an expeditian north an the coast in 1540 , primarily to support Francisco Vasquez de Coronado's overland venture. Three vessels fitted at Acapulco and led by Hernando de Alarcon sailed up the Gulf of Califarnia where, apart from exploring the Colorado River, they waited in vain for a signal from Coronada. In November of 1540 the party returned to part in Colima, as its arders stipulated.13

After one failed mission in 1542, later that same season Juan Radriguez Cabrillo sailed norttward on Vicergy Mendaza's orders to search for the Northwest Passage. Cabrillo met with no luck, but he traversed the coast as far as San Francisca without, however, espying the bay.14

Cabrillo died before the vayage cancluded, and to add insult to injury, the accomplishment af having sailed so far north was tushed-up, in keeping with the official spanish penchant for secrecy. Suct policies would be significant with regard to later voyages.

$1=$ Mendaza's arrival in 1535 afficially supplanted Cortes's authority, although since the late 1520 's a rayal. body, the Audencia, tectinically wielded the highest manifestation of Spanish regal authority. See Haring, passim.

$1=$ Holmes, $92-98$.

- While it may seen curious that ane cauld sail to ar past San Francisco without espying the bay, such is the Pacific coastiine. With some regularity prominent features of the littoral were often past unmoticed. Both cool: and Wagner attribute the phemomenon to endemic foggy weather and to a reluctance of mariners to stray too close to store. 
The next important incursion into northern Pacific waters was not by a Spaniard at all but rather by an Englishman, the redoubtable Sir Francis Drake, who set sail in 1577 with a complement of five ships, with he himself commanding from the 180 tan Golden Hind, the anly vessel that survived the expedition. Two aspects af his expedition are relevant to this study. First, the intrepid knight seaman rounded Cape Harn and subsequently both raided Spanish coastal. settlements and seized the Manila Gallean. Spanish authorities clearly and understandably tool: alarm at the seeming ease with which Drake operated. Second, his mission, libe Cabrilla's, had orders ta search for the Northwest Passage and, ta that end, met with no more success than the unfortunate Spanish mariner.

\section{THE MANJIL GALLEON}

Spain established the Manila Galleon, an annual trade canvoy running between Manila and Acapulco, in 15E5, 44 years after Ferdinand Magellan claimed the Philippine lslands in the name of the Spanish Crown. Magellan, a disaffected Portuguese mariner, had thrown in his lot with Spain in 1517 and while in its employ became not anly the first to navigate the treacherous waters of Cape Horn but the first to circumnavigate the planet. $x=$

$1=$ William Lytle Schurz, The Hanila Galleon (New Yart: E.P. Duttan \& Co., Inc., 1939) 17-18. See also the chapter titled, "The Manila Gallean," in Richman, 12-30. 
Following Magellan's return to Spain in 1522 several expeditians--including thase af Garcias Jofre de Loaysa in 1525, and Sebastian Cabot in 1526--attempted to retrace his route, without success. In 1542 six ships duplicated the feat, but accomplished "nothing lasting.' did colonial afficials determine that annual trade with the islands constituted both a desirable end and a feasible goal. of voyages averaging six manths duration the service shuttled goods to and from the islands and Mexico, many of which eventully reached Spain.

The fright given Spanish authorities by Drake's exploits compounded the fact that until. 1579 the Gallean had been without--indeed, without the need for--any pratection. Spain's considerable success in largely hiding the trade's existence goes a long way toward explaining its preoccupation with maintainimg strict secrecy about these vayages. $x>$

\section{SEARCH FOR THE STRAIT OF ANIAN}

Drake's quest to find the Northwest Passage mirrors a similar angoing Spanish colonial preaccupation. More commanly bnown as the Strait of Anian, the passage reputedly 1 inted the two great aceans, Atlantic and Pacific. Desperately sought by the geographically disadvantaged

\footnotetext{
$x=$ Rictiman, 13.

17 See Cual:, 7.
} 
English--and by all her European rivals--a strict economic

imperative guided the search for the elusive strait:

The importance of transoceanic transport for the importation of commercial products from the orient was due to the fact that carriage by land in the sixteenth century, as today, was very costly; and so slow as to impair the quality of these products, chief of which were spices, while in transit... It was estimated at venice that products costing a ducat in the Far East became worth from seventy to ane hundred ducats when they arrived there. By thie time they reached the western extremities of Europe the cost was still further increased; thus it iss no wonder that both the English and the French merchants were eager to find an all-water route free from Spanist and Portuguese interferences. 10

In what proved ta be horrifying for Spain, in 1587 Thomas Cavendish successfully duplicated Drate's logting of the galleon. Spanish authorities immediately imagined that Cavendish--and, by extrapolation, pirates in general--had found and had begun ti ply the Strait of Anian. This fear and two ather factors fundamentally convinced Spain to return to the northern coast. First, the galleons and their crews had long suffered because the ave: iaden vessels spent so long at sea that both ships and sailors literally gave out--sinking and dying with devastating regularity. Settlements on the northwest coast might ameligrate these abysmal conditians since typically the galleon first sighted land hundreds of miles morth of Acapulca near Cape Blanco, California; thus, settlements in Alta California could relieve some of the pressures wrought by overlong stays at 
sea: rotting timbers might be replaced, or scurvy could be treated. Second, the new viceray, Luis de Velasco (1590-95), "exceeded his predecessors in zeal for discovering this Passage , 19

John Cabot's vayage to Cape Ereton Island on Canada's east coast in 1497 aroused the earliest interest in the passage. The idea first appeared in print in 1527, and by 1540 mapmaker Sebastian Munster had drawn a facsimile of the putative strait. A Flemish cartographer, Abratam Drtelius, created the second such map, said ta be of Italian origin. These earliest purported set af directions point ta the remarkable fecundity of the human imagination: Munster's theary rested an America being an island separated by water at its northern coast from two other large isles; zo ortelius followed a more traditional approact and fancied the passage an actual sea-lane along the narthern fringes of a single continent, North America.zi Subsequent claims pointed both morth and south. Drake's voyage, of course, demanstrated that no southern passage existed. So, literally, given the

15 Cook, 10. As noted, Drake also sought the strait, however, he turned away from the Northbest coast afficially at 48 degrees North latitude. There has been some debate as ta the veracity of this "afficial" claim, first published in 1E28. Wagner, for example, compeliningly argues that Drat:e turned out to sea at a point no further north than 43 degrees. Moregver, Cout: charges, the English claim was purposely doctored for political reasons. See Henry R. Wagner, Sir Francis Drake's Voyage Around the World: Its Ajms and Achievements CSan Francisco: California Historical Society Press, 1926) 135-43. See also Cooti, 7-8.

20 Wagner, Spanish Voyagas, 359.

a Ricl: 1 and, $1 E E$. 
nature of the speculation, mapmakers returned to their

instruments and their imaginations.

Not unexpectedly Spanish authorities were not immune to the persuasive powers of suct, notions, and, as noted, by the early $1590^{\prime}$ s had urgent reasons far a narthward thrust both of explaration and of limited settlement. Where cortes had sought riches, more glary, and potential Christian converts-for he was a pious manaz--the newer impetuses, while not blind to these lures, were mare defensive in scope: essentially colonial officials wanted to protect a good thing, and, additianally, if possible acquire mare of it. But, primarily the hope for a new, safe, stop-over port engendered the next visit to the northwest littoral.za Sebastiag Rodrigues Cermentud directed the gallean ta Manila in 1594 and on his return sailed as far north gn the American coastline as about $30 \mathrm{miles}$ south of the $42 \mathrm{nd}$ parallel, the California-Oregon Barder.z-He later landed

s: With trenchant accuracy Cortes immodestly recorded: - I have toiled without cease for 40 years, eating pourly, through times good and bad... placing myself in danger, spending my fortune and my life, all in the service of Gud. I brought stieep into His fold in unknown lands... while gaining for myself appropriate wealth and esteem." Cited in Peggy k. Liss, Mexiso linder spajn, 15it-1556 chicagos The University af Chicago Press, 1975): 21.

za The ensuing voyages of Sebastiag Rodrigues Cermentio and Sebastiano Viacaino may tiave been influenced by yet another mythical tale--the vayage of Juan de Fuca in 1592 to the strait bearing his name. Fuca claimed ta have found, entered, then returned from the passageway at a latitude almast exactly where the straits of Juan de Fuca now exist. Whether ar not Fuca's vayage actually took place has been a matter af same cantraversy, which will be discussed in Chapter II. See Cook, $22-31$. 
near Drate"s Bay, California, and formally took possession for the Spanish Crown. $=$ While ashore the landing party witnessed the ship's destruction by a squall. Incredibly, the 70 or so survivars continued in the shore launch to a safe port, but proved unable to fulfill the ather, essentially cartographical tast of the mission.

The next expedition northward put ta sea in 1596 , captained by Sebastiano Vizcaino, with a first royal order ta establish a calany with a satisfactory harbar an the Eaja California coast. Despite the aridity Viacaing attempted a settlement at La Paz-with no success. Respecting the wishes of Philip III, wha ascended the Spanish throne in 1598 , Vizcaing returned to northern shores in 1602, outfitted with a year's supplies. The flagship san Difgo managed to attain a latitude of 42 degrees North; a secand vessel, the Santo Tomas, foundered at sea; the third ship, the Tres Reyes, reconnoitered the coast at lower levels, and rendezvoused with the San Diego in 1603 at the part of Acapulco. This

24 This curials enterprise found Viceray Velasco reluctant to allocate funds for the expedition from his own budget, although he fully supported it. Cermentia, meanwhile, insisted trat sufficient monies be given him in the event that the party 1 and in such fareign parts as where money might be required. The campromise reached gave cermentia access to the funds of the returning galleon-which wouldn't affect Velasco's financial statements--thus he set sail fur Manila. Wagner, spanjsh Voyagas, 155-5E.

$z=0 f$ considerable legal and symbolic importance the issue af "taking-possession" will be discussed in Chapter I II. 
remained the last planned expeditionzes to the northwest

coast until vessels arrived at Monterey in 1769.

By this time, Spanish afficials were apparently

convinced that discovery of the strait--and it would be considerably to the north the numerous voyages had demonstrated--cauld anly lead to its explaitation by interlopers. Such an event, colonial officials believed, would directly threaten the security af New Spain's northern frontier, as well as its productive silver mines. Of course, while this argument abviously overlooks the fact that the passage might be discovered from the east which would presumably lead to the same unfortunate result for spain, the literature is silent. Henry Raup wagner notes nathing more than such explaration in the east "always elicited the interest of the Council of the Indies." Additianally, fever for the imagined northern wealth for the most part had subsided. The "timber, grain, fruits, petraleum, and the multitudinous products which now bring wealth to this region were valueless or would have been had they been

20 It is necessary to qualify this statement i.e., use af the word "planned" ") because archaeological evidence tas revealed that a vessel went down off the oregon coast at about 45 degrees North latitude early in the eighteenth century. The wrect: littered beaches with beeswax which subsequently served as a trade item for tie native Americans living nearby. "The best educated guess" indentifies the stip as the 1707 Manila Galleon, San Francisco Kavier. See Donald C. Cutter, "Spain and the Oregan Coast," The Hesters Shore, ed. Thomas Vaughan (Portland: oregon Historical Society, 1976) 37-38. See alsi Cabl, $31-35$. 
produced." $=>$ fild the rugged coastline itself often

presented an uninviting visage.

Clearly, a flexible myriad af forces predicated Spain's early north coast trirust, including a desire to christianize and an ephemeral urge to settle, a lust far riches and adventure, and a concern both to find and to protect from alien penetration the Strait of Anian. Yet a full understanding of the expeditions necessarily depends on placing them into a socio-cultural context. While a representative picture of the whole of colonial Mexico is not required, it is instructive ta delineate certain salient elements of the society from which the early voyages were launchied.

\section{COLONIAL SDCIETY IN NEW SPAIN}

The fundamental social, cultural, and economic premise af Spain's effort in Mexico served to make the colony as much like the Mother Country as possible. Careful grogming would guarantee, among ather trings, perpetual dependence. This accurred both as a conscious administrative effort, and at a more subtle level, as the new settlers were, after all, products af a certain environment. In short, New Spain's raison d'etre dictated service to the same twin towers--God and Potentate--as its parent. ze

\footnotetext{
$\Rightarrow$ Wagrier, spanish Voyages, 284-85.

2e Timathy E. Anna, "Spain and the Breatidown of the
} Imperial Ethos: The Problem of Equality," Hispanic American Historical Reujer E2 (1982): 254-72. See also Haring's 
New Spain's administrative structure cast a mirror image af the strict hierarchy of the mother country. Atop the colonial peak sat the viceroy as sat the monarch in Spain.2: All secular autharity derived from this fount except, of course, that the viceray answered to the crown. A series of lesser officials campleted the corporate ladder.30 For comparative purposes, the salient feature to note was its heretical nature vis-a-vis the North American Loct:ean traditian.

Yet still above the potentate sat God, whose commanderin-chief on earth, the Pope, held the monarch morally responsible and accountable for his or fier actions. The yardstict: af the juridical canons of the one True faith, Romar Catholicism, measured the ruler's actions. In fine, Spain's political system bordered on theocracy. Litewise, in New Spain the church expected colonial afficials to act with unctuous piety. And as the pyramidal shape of colonial

seminal wort, The Spanjsh Empire, the political discussion af which is especially illustrative. For the spiritual bridge between Spain and New Spain see Charles Eraden's ReIigious Aspects of the Conquest of Mexico. The economic relaticunship is carefully investigated in Lesley Byrd Simpsan's The Encomienda in New Spajn CEerteley: University of California Press, 1930).

2 It will be recalled that until the late $1520^{\prime} 5$ Cortes, in effect, governed the colony, and that the first viceray, Antonio de Mendaza, did nat arrive until 1535.

ac While far beyand the scope of this paper the "corporate", system has been identified as sa profound a phemomenon that it exists in modified farm even today. In her study of sixteenth century New Spain, Liss writes, corporatism "was a way of thinling order into diversity...a theary emplayed by central authority to facilitate control...embedded in langlage and religian.' Liss, 145. 
administration mirrored the top-down model af the old world, so too did the New World churct mimic its Iberian parent. That is, the archbishap (i.e., New Spain's pape) balanced the vicergy (i.e., New Spain's monarch).

The theocratic nature of colonial society explains the missionary impulse that played a part in virtually every early voyage northward. Clergy were deemed as necessary to such expeditions as bread and fresh water. The most obvious example af just how deep this motian lay bedded in the Spanish psyche is that the Conquest of the New World could be justified anly insofar as it successfully spread God's word, an crder unequivacally spelled but by Pape Alexander VI's Papal Eull Of 1493. $\rightarrow 1$

Spain's ecancmy can best be described as mercantilist, a label also applicable to its European rivals. Yet the peculiar Spanish variant of this economic theory stressed the accumulation of bullian gver trade per se. This idea " was conditioned by the prevailing belief that gold and silver alone constituted wealth," according to Professor Clarence Haring. "Each nation," he writes, "must keep what it had and get as mucli as possible from others... Mercantilism was essentially a protectionist system." a result, the mother country momopolized trade. Thus, as a religious imperative fueled the spiritual. Conquest and played a role in the early pust up the western littoral, so

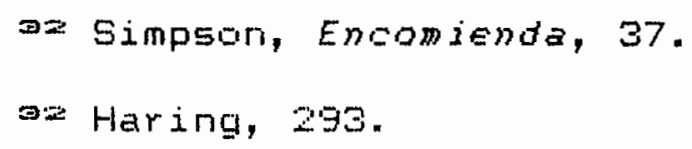


a lust for riches underscored Spain's interest in Mexico and beyond. "We came here to serve God, and also to get rich,"' conquistador-historian Eernal Diaz noted. as In no small measure then, Spain kept Mexico for the profits, and likewise abandoned the north coast for itg apparent dearth of $r$ iches.

The empiricaliy difficult to measure concept af sense of adventure as causative agent thrived in New Spain's early expansion and exploration. To this extent, the stereatypical image of conquistadom as indamitable rogue is quite accurate. The language used to describe the voyagers-"explorers," 'discoverers,' and so on--connate the evidence needed to substantiate the point. Irving Leonard's Eooks of the Erave, far example, canvincingly demanstrates how sixteenth century Romantic literature bath engendered and manifested the ubiquitous will to adveriture. $\$ 4$ Gold, Glary, and Gospel, says he, were super-charged imperatives driven by the written word:

After 1500 particularly tis [the conquistadar's] imagination was kindled to ari almost mystical exaltation af adventure and romance by the many bouks which began to pour from the presses.os

$\exists$ Cited in Liss, 20.

04 Irving A. Leonard, Books of the Enave Cambridge: Harvard University Press, 1949), passim. 
HAPSEURG RLLE

Very broadly speatiing, official colonial life was neither static nor especially active during the sixteenth and seventeenth centuries. A time of greater range far individual decision making by the viceroy and his subordinates marked the former hundred years, while the latter periad witnessed increasing centralization of decision mating. This change directly reflects the vagaries af the ruling House of Hapsburg, truly a dismal lot. Colonial administration, as a result, performed sluggishly and inefficiently. For example, if nothing else, the manths spent at sea for ordinary correspondence to reach Mexico (and vice versa) meant important decisions sat in limbo. Marecuer, the crown concerned itself less with campetency than with loyalty in its selection of candidates for postings in the New world ar in the apparatus of gavernment in Spain. $\$ 6$

The crown unified in 1478 under Ferdinand of Aragon and Isabella af Castille after centuries of struggle between competing princedams. When the queen died in 1504 the whole peninsula, save for Portugal, fell under Ferdinand's regency. $a>$ when Ferdinand died in 1516 his grandson, Charles

$\Rightarrow$ A.W. Lavett, Early Hapsburg Spajn, 1517-1598 coxford University Press, 1986) 83-97.

$\Rightarrow>$ Isabella willed that her daughter, Juana, infierit the possessions of Castille. The princess, however, proved unequal to the task because af mental instability; thus, in beeping with the queen's instructions, Ferdinand assumed contral. 
V, ascended the throne with dominian aver Spain, Naples, Sicily, and the Spanish holdings in Africa and the Americas. Additianally, he inferited title to The Netherlands and to lands in Germany from his paternal Hapsburg grandparents, Marie of Eurgundy, and the Holy Roman Emperar Maximillian.

Despite grandigse plansoo and considerable energy, Charles $V$ gaverned ineptly. Ascending the thrane totally ignarant of Spanish, Charles forcefully attempted to redirect trie monarchy, and "ruled as a traditional dynast, governing as averlord." His new subjects immediately viewed him with 'suspician, then open hostility," angered at the prospect af serving a "foreign-born and foreign-reared king and his non-Spanish, rapacious officials and courtiers." 9 A failed revolt against the ring's doctrinaire absolutism in 1520-21 left Charles--and the House of Hapsburg--firmly ensconced as ruler of Spain. When he at length renounced the throne in 1556 Spain iay prostrate, bankrupt and heavily in debt to German and Italian investors.

His san, Philip II, proved to be of no greater stature than the father. Though the taking of Portugal in 1580 increased naval strength, war with Eritain utterly devastated Spain's mighty Armada in 1588. Then, from Philip's death in 1598, the picture for Spain only worsened.

se Charles saught, for example, ta marry aff his son to Mary Tudar of England, which would have effectively united the ruling houses of the world's greatest maritime power, Spain, with its heir apparent. Mary's untimely death in 1558 scuttled the plan. 
The first two of the three seventeenth century Hapsburg monarchs--Philip II (1598-1E21) and Philip IV (1EZ1-16E5)-managed to lose muct, of The Netherlands, Flanders, Luxembourg, Portugal, and other holdings. Weat: and incompetent they chose to leave the work of government to hand-picked favorites. The rule of Charles II, last of the Hapsburg line, proved even more disastrous for the spanish Empire. He has been judged "the most degenerate, and the most patretic victim of Hapsburg inbreeding...mentally subnarmal... no more than a cipher, a shadow ting.4o

As its European rivals inexarably eclipsed Spain, the colany advanced slowly, reflecting the character af Hapsburg rule. Despite the extraction of great wealth fram extremely productive silver mines (bullian!) the mather country siphaned aff virtually all the profits ta service its many debts. Meanwhile, colonial policy so restricted trade in New Spain that only one port, Veracruz, remained open far business; and to it could only come goods from the trade manapolists at Sevilie and Cadiz. Moreover, exhaustive mercantilist regulatian severely hampered calanists' ability to establish indigenous industries while, given the nature af manopoly, the imported goads commanded unreasonably high prices and frequently exhibited poor wortimanship.

Under such conditions it is not surprising that smuggling plagued Spanish officials in the Gulf of Mexico,

4c John Lynch, Spain Under the Hapsburgs COxford: Basil Blackwell, 19E9) 229. 
despite the fact that it merited punishment by pain of death. As the sale of contraband thrived, the Spanish and calonial economies suffered because smuggling precluded both Spanish profit-making and the collection of potential tax revenues.

Iranically, the Church in New Spain thrived under Hapsburg rule, especially during the seventeenth century. This institution amassed ever mare substantial tracts of land--rendered, incidentally, quite unproductive--and actieved an hegemanic position, not unlike the Medieval

Churcti in Eurape:

...the Spanish church in America, managed ta create a vast material base that ultimately reactied into every carner of the newly converted Indies. Apprehensive of clerical power while at the same time canvinced that restriction on rights to property would spare the church material concerns that might interfere with its spiritual mission, the crown sporadically opposed, but in the end was unwilling to limit, the income of an institution that provided the fundamental social catiesion in a disparate but pious empire.4

The Church acted as the principle maney lender in New Spain and, as the Inquisitian reached its lang arm across the Atlantic, in a metaphorical sense the one True Faith provided banking services both temporally and spiritually. As the eighteenth century beckoned New Spain had in a very real sense been isolated from international trends and

41 Arnald J. Eauer. "The Churcti in the Ecanomy af Spanish America: Censos and Depositos in the Eighteenth and Nineteenth Centuries," Hisfanic American Historical Review ES (1983): 707. See also Irving A. Legnard, Earoque Times in old Mexico (Ann Arbor: University of Michigan Press, 1959) 221. 
developments. Although the mother country sought the greatest possible return on its investment, from bad government in Iberia came ineffectual. administration vis-avis explaitation af the colany. Administrative inertia smothered al1 the elements promating exploration discussed earlier. The Conquistadores had been supplanted, on the one fiand, by settlers, and on the gther hand by lack of success i.e., they found neither bullian nor healthy adventure on the Northwest coast. Additionally, in keeping with colonial policy, Spanish afficials who had little interest in continuing such vayages usurped the power of these individuals, as for example, when Viceroy Mendoza supplanted Cortes in 1535. Even the Roman Catholic Church contented itself with madest advances inta the narthern frontier. When Charles II, "El Hechizada," the bewitched, died heirless in 1700 a decade-lang struggle ensued far contral af the Spanish throne and a new age dawned.

\section{THE WAR OF THE SPANISH SUCCESSION}

Although the great powers of Europe grappled in the war of the Spanish Successian far the right to determine who would replace Charles II as Spain's monarch, iar the purposes af this study it need not be afforded much detail. Certain salient elements are important, however, because the new royal family returned Spain to near greatness, and reestablished the Spanish presence on the Northwest caast. 
Two would--be Spanist kings vied for positian as death hovered about the bed af Charles II: Archduke Charles af Alustria, younger son of the Holy Roman Emperor Leopold; and Felipe of Anjou, grandson to Louis XIV of France. Charles, in one af his more cogent moments willed his throne to the capable Felipe, a decision duplicated by Louis XIV. England, startled by the prospect of facing a united front af france and Spain that this succession would engender, went to war to prevent it, and received support from Austria, The Netfierlands, Portugal, and some small German states. The figtiting began in 1702, continued until 1713, and officially ended with the Treaty of Utrecht. 42

While the House of Bourbon garnered the Spanist throne, Eritain gained major trade concessions in the Spanish Indies (bnown as the Asjento), a guarantee that the royal houses of Spain and France would not unite under Felipe and, additionally, England gained the strategic outpost of Gibraltar. Moreciver, another treaty concluded the following year gave away what possessions Spain still held in The Nettierlands, while Austria received lands in Italy. Yet remartably, the Spanist, House of Eourbon would rally to overcome these and other formidable obstacles. 


\section{CHAPTER I I}

\section{RETURN TO THE NORTHWEST COAST}

The first three expeditians to the northwest coast in the eighteenth century sailed during the reign of the Eourban monarch Carlos II I (1759-1788), who has been considered one of Spain's mast illustriaus monarchs. Under the aegis of the so-called Bourbon Reforms, his far-sighted policies returned Spain to near greatness through continued centralization of government, improved efficiency, and bolstered defenses. In New Spain the successful implementation of royal policies and desires required especial competency in two key positions. First, the accomplishments af Visitadar Jase de Galvea represent the manifestation of the Enlightened philosophies guiding Carlos's thinking; and, secand, the viceregal administration of Antonio Eucareli illustrates the critical perfarmance expected of a viceroy.

Galvez's service to the crown punctuated Carlos's reign, initially as visitor-general to Mexica (1765-1771), and later as Minister to the Council af the Indies (177E1787), the Spanish body respansible for colonial administration.1 Galvez's unyielding desire to ensure that

* Since its inception in 1524 the Council af the Indies had directed the Crown's affairs in the Americas. It reached the nadir of its power in the sixteenth century, after which 
the crown's policies be adherred to, as well as his own recommendations for improvements, necessitated that he be involved with planning the expeditians to the northwest coast.

Incarparated into the consequent roles of Galvez and most intimately tied to the explaration is the period 1771 through 1779 during which Antonio Bucareli served as viceroy af Mexica, and during which the voyages were launched.

Eulogized as an exemplary viceroy, Bucareli in fact planned and directed the expeditions.

The raison d'etre af the vayages af the 1770 's can best be understoad by first examining salient elements of the reigns of the eighteenth century Bourbon monarchs. The achievevments of Galvez, Bucareli, and the importance of several influential apocryphal voyages likewise serve to illustrate the causal agents that engendered the Perez (1774), Hezeta-Egdega (1775), and Arteaga-Bodega (1779) expeditions.

\section{BOURBON KINGS}

When Felipe $V(1700-1746)$ assumed the thrane in 1713 following the War of the Spanish Succession he inherited a natian in stiambles. The economy, always sluggish and inefficient in wholly lethargic Hapsburg hands, had been devastated by the demands made on it by the conflict. Trade 
with the colonies earlier fell short of its potential because of the restrictive monapoly systems but, as a result af the war, Spain lost a substantial share of its ecanomic sovereignty due to trade concessions and debts incurred to fund the conflict. Further, Spanish military preparedness had declined precipitously, until it was represented at sea-the nation that had launched the mighty Armada of 1588 --by a puny naval force of 20 warstips. Equally telling, the spirit of the infantry had been so broken and the incentive to fight had become so negligible from endemic Spanistı losses that traops often ran away from battle.

Undaunted and with vigor, Felipe took up the challenge to rebuild the Iberian nation. He ruled over a truly Spanish--and consequently more manageable-mempire, consisting of the kingdams of Castile, Aragan, plus possessians in the New World. His first reform measure saught to reduce interlopers' penetration af the colonial economies. The Treaty af Utrecht (1713) had exacerbated the smuggling problem by the Asiento giving Eritain a foutrold in Spain's New World slave trade, and the right to send one annual shipload of merchandise to the colony. Smugglers capitalized an both concessians, using the sanctioned trade network as a thinly guised conduit for contraband. Spain responded by commissianing privateers to patral New Spain's Atlantic coastline in search of illegal vessels, which led to war witti Eritain in 1739. Related to his first Eourbon reform palicy, Felipe's second policy attempted to revive 
the torpidly slow flota system, an easy and aft targeted spoil for interlopers. Eut by engaging Eritish natianals in combat the Spanish privateers further roused the island nation, and in 1740 Spain temporarily suspended the flata system after losing the war.

The ultimate solution addressed the problems in two ways. On the one hand, Spain replaced the ponderously slow and difficult ta defend galleons with newer, lighter, and much quicker vessels whict typically sailed singly. And on the other hand, when danger appeared to be minimal the crown simply re-establistied the flota system.

Felipe made no attempt to re-structure colonial administration, but rather sought to improve it through a process stressing increased centralization, and by improving the quality of officials. The Crown, for example, largely eliminated the sale af offices to the highest bidder without regard to qualificatian. = Other administrative improvements included moving the afficial port from Sevilie to Cadiz, $a$ a better, more efficient harbor, and doubling ta two the

: Despite appasition fram the Council af the Indies, Eourbon monarchs, always in need of revenue, never completely abandoned the Hapsburg practise of the widespread sale of powerful and prestigious offices. See Mart:

Burticidder, and D.S. Chandler, 'Creale Appointments and the Sale of Audencia Positions in the Spanish Empire under the Early Ecurbons, 1701-1750." Joumnal of Latin Amemican Studies $3-4(1971-72): 187-206$.

- Seville's proximity to Spanish agricultural lands, which stricked vessels sailing to the New World, had traditionally disadvantages the superior harbor site of Cadiz. Lovett, 84. 
annual number of ships allowed to trade between Manila and Acapulco.

This first Spanish Bourbon monarch stumbled badly in international affairs, frequently involving Spain in armed conflicts, especially with Eritain; and, with similar frequency, losing. Galvez's biggrapher, Professar Herbert I. Priestley, attributes Felipe's diplomatic troubles to three things: Felipe's blind desire to regain title to the French thrane; a desire ta re-gain Minorca and Gibraltar; and, the desire of tis wife, Isabel Farnese, 4 to establish her sons in Italy. $=$

On Felipe's death in 174E, Fernando VI, the secand but anly surviving son af his first marriage came to the thrane at the age af 33. Less aggressive than his father, Fernando's only substantive achievement seems to have been to continue the former's policies, with the notable exception of keeping Spain gut af costly wars. Thus, the Iberian nation would eenjoy fourteen years af muct-needed peace, during which the improvements introduced by Felipe ci.e., further centralization of power and increasing mercantile efficiency) tock: firm rogt, , E but during

* Isabel's cansiderable influence on the king has been attributed to Felipe's insatiable sexual appetite. The result: "Philip was at the same time the tyrant and the slave af the woman he loved." Charles Petrie, king Chamles IJI of Spain. An Enlightened Despot Condan: Constable and Co., 1971 ; 3 .

- Herbert I. Priestley, Jose de Galver, Visitor-General of New Spain (1765-1771) (Berteley: University af Califarnia Press, 1916) 14-15. 
Ferdinand's tenure colonial policy and administration

changed little.

The reign of Fernando's half-brother, Carlas III, who ruled from 1759 till his death in 1789, achieved an opposite effect and returned Spain to near greatness. A series of far-sighted policies revived the imperial econamy, both at rome and in the colony, and defenses were bolstered an every shore. While one must not exaggerate Carlos's successes--the essence of mercantilism survived, and Spain was inexorably eclipsed by European rivals--for a brief time his policies narrowed the ever widening gap.> Far a significant part of Carlos's reign one tey figure, Jose de Galvez, served the Crown both in New Spain as visitor-general (1765-1771), and in Spain as Minister of the Indies (1776-1787).

\section{VISITOR-GENERAL JOSE DE GALVEZ}

The visitador's functions and responsibilities were clear, according to Haring:

Visitas were af two sorts, which may be called specific and general. The former applied to a single official or province; the general visita was an inspection or investigation of an entire viceroyalty or captaincy general. Everything came within the purview af the visitador-general, from the conduct of viceroys, bishops and judges to that of the local parish priest; although when a

E Eernard E. Erobb, The Vicemegency of Antonio Mamia de Eucareli in New Spain, 17T1-1779 (Austin: University af Texas Press, 1962 ) 13.

7 In a well researched study, Jase Cuelia traces Baurban reform measures in a localized setting. "The Econamic Impact af the Bourban Reforms and the Late Colonial Crisis of Empire at the Local Level." The Americas 44 $(1987-88): 301-23$. 
viceray was included in a visita it was anly in his capacity as president of the audencia cthe chief administrative bady in the colony]....

Galvez's visita was af the general type, and he is

universally hailed as a visitador without equal. Rising from the lowly station of shepherd boy, he served energetically and usually successfully, even though suffering a bout af madness in 1769.

Trained as a lawyer, and appointed visitar-general February 20,1765, his arders from the king, in part, read: ..you may, in the capacity of visitor-general of all the brancties, revenues, and duties, which in any form appertain to my real hacienda [public financel within the jurisdiction of the kingdom of New Spain, take cognizance of all of them, examine their proceeds, expenses, balances, and the whereabouts of their funds; demand any arrears in which the administrators, treasurers, lessees of revenues, or other persans who have managed rents, may be to my real hacienda; and regulate the system and management with which the revenues are to be administered in future, reducing expenses and salaries which can and ought to be lowered or abolished, so that the balances be not dissipated by unnecessary expense, but made more effective to their destined ends. 10

- Haring dates the first visita to 1499 , an investigation of the government of Christopher Colambus. Intent on unseating Viceroy Mendoza, Cortes in 1540 apparently persuaded the Council af the Indies to employ a visita to investigate his arch-rival, but it came to little effect. Haring, $142-43$.

- The pious and proper visitador became irrational during his tour of the northern provinces in $1769-70$. Apparently, so powerfuliy did the fears of Russian encroachments play upon tiss mind that he suffered wild delusions, imagining himself, variausly, to be the ling of Prussia, Sweden, the pope, and St. Francis of Assisi. Within months he recovered completely. See cook, 53-54. 
Galvez arrived in New Spain on the heels of Carlos's many orders designed to revitalize the Imperial and colonial economies. The sequence is important, because although the Crown hoped to invigorate the colonial economy, the underlying premise always concerned the welfare of the mother country. His initial plans centered on establishing a government tobacca monopoly from which Spain might re-coup financial losses it suffered in the Seven Year's War (175E1763), in which Spain lost Florida and almost lost Cuba; rooting out corruption, for example, by reforming the customs house at Veracruz; and, most importantly, bolstering defenses an the narthern frantier.

Galvez established the tobacco monopoly almost immediately after his arrival, during the viceregency of the Marques de Cruillas. An early failure, the corporation thrived after 176 e when Carlos Francisco de Craix replaced Cruillas, whom Galvez did not like. 1 The collection of custams duties had been the prerogative of certain contracted parties since the 1500 's but Galvez returned the service to colonial administrators as contracts expired. Mareover, the Council af the Indies adapted his recammendations and apened additional, competitive ports at Campeche and Yucatan. $1=$

11 See Priestley, Chapter IV, "Galvez and Cruillas-The Tobacco Monopoly,", 135-71. 
Frontier fortification is best seen in the light of expulsion af the Jesuits from all Spanish daminions in 1767. Carlas III issued the order in part because the society of Jesus represented the most obvious challenge cwith significant symbolic avertones' to the "Enlightened Despatism' 'f the Bourbons. In Lesley Eyrd Simpsan's words, - The Jesuits had become too powerful for their own good." '13 Additicnally, certain powerful, anti-clerical officials convinced the king the order planned to depose or kill him." Yet the push northward either by sea or by land always stemmed at least in part from proselytizing imperatives, and so an effective defense of the frontier meant essentially to defend the manifestation of the very institution (the Church) whose prerogatives the crown sought atherwise ta subardinate to its own, mare secular interests! Galvez began a first inspection tour of the frontier provinces in April of 1767 . The situation at the presidio af El. Paso in 1765 typified the dangerous and frequently chactic conditions. Guarded by fifty men, over whom a captain wielded supreme military and civil authority, 13 the

13 Lesley Eyrd Simpson, Many Mexicos CBerkeley: University of Califarnia Press, 1941 ) 200.

14 Engstrand, 440.

$1=$ A number of specific actions dealt with the northern frontier problems. Most importantly, Galvez capitalized on the opportunity Julian de Arriaga's death left him in 177 , replacing him as Minister of the Indies and initiating a proposal that re-structured New Spain administratively by establishing a whole new sub-viceroy. Under the plan several northern province were removed from the jurisdiction of the viceregent and placed under the command of a captain- 
averriding concern involved defense against hostile Indians, whose lands they had invaded. In his diary the outpost's commander, Jose de la Filente, appeared ta be totally preaccupied with "the enemy Indians." During the month af September he recorded:

On the twentieth the Apache Indians stole twentyane head of cattle belonging to don Alanzo de la Cadena, a citizen of Chifiuahua. of these they made off with nine, while the other twelve were taken away from them by five Indians af the village of Senecu [about five miles southeast of Ciudad Juarez] who were out hunting. Two of the animals died of wounds received by the Apaches.1.

During September and October of that year Fuente reported a net $105 s$ of 18 oxen, 21 cattle, and an undisclosed number of mules to Indian thievery. The Spanish retribution netted six dead Indians, and seventeen taken prisoner. 17

Just two days gut of Guadalajara Galvez received a communique from Spain's Secretary of State, the Marques de Grimaldi, via Viceroy de Craix, instructing him to take immediate action to counteract recent Russian encroachments toward California. Galvez interrupted the northward

general, who represented the Crown directly, and acted both as supreme civil and military authority. The premise was simple: to relieve the viceroy fram nagging problems an the frontier that might be better addressed by a military man. Eucareli's strong apposition delayed its implementation until 1776. See Charles Edward Chapman, Chapter XXV, "The Commandancy-General of the Frontier Provinces," A History of California: The Spanish Period (New Yart: Octagon Baolss, $1928) 316-2 \exists$.

1. Jase de la Fuente, "Diary af Pedra Jose de la Fuente, Captain af the Presidia af El Pasa del Norte, August-December, 17ES,', trans. James M. Daniel, Southwestern Historical Quarterly 83 (1979-80) 259-78. 
expedition and months later, in 1768, a junta composed of Galvez, de Croix, the archbishop, the judges of the twa audencias Cheadquartered in Guadalajara, and Mexica City, respectively) and ottier important officials, met to address the royal concerns. Priestley cites eight problems the junta sought to redress, including such things as counterproductively high export duties, agricultural stagnation due to a lack: of black slaves, and lax enforcement of regulations. 10 More to our point, however, the junta very directly expressed cancerns with putative Russian encraachments on New Spain's Pacific frontier, and in a joint despatch issued to the Council af the Indies noted:

It is known to our court by the voyages and narratives that have been publistied in Europe that the Russians have familiarized themselves with the navigation of the sea of Tartary, and that (according to a well-founded report) they already carry on trade in furs witt, a continent, or pertaps an island ([Alaska]), distant only eight tundred leagues from the western Coast of the Califarnias...

Additionally, it continued:

...that from the year 1745... the English and Dutch have acquired a very particular knowledge of the ports and bays we hold on the south coast, especially the peninsula of the Californias; so trat it would be neither impossible, nor indeed very difficult, for one of these nations, ar the Muscovites, to establisti, when least expected, a colony in the port of Monterey.

Officials in Spain were cognizant of the Russian danger, tiaving been warned as early as 1761 by the Duke of

10 Most of the issues were af purely administrative focus. Priestley, ZE-31. 
Almadovar, Spain's representative in St. Petersburg, that Russian fur-traders had been moving ever nearer spanish dominians. However, Galvez and de Croix's remonstratians further highlighted the need for action, and prompted the establistiment of the Naval Department at San Blas in 1767 and the missian at Monterey in 1769.20

\section{THE NAUAL STATION AT SAN ELAS}

Russian north-Pacific exploration and exploitation had been well knawn for some years, and served to re-activate Spain's sixteenth century fears af fareign meddling on its colanies" western littoral. To that end, the naval station constructed at San Elas in 17E7-68, and the settlements established at San Diego and Monterey in 1769 canstituted Ealvez's respanse to the Spanish Secretary af State Marques de Grimaldi, Minister of the Indies Julian de Arriaga, and the expressed fears of the junta.

Clearly, any expedition sailing north to Alta Califarnia (and beyond) needed a suitable launcting port, yet it is somewhat surprising Galvez favored San Blas. Drifting silt deposits frequently rendered the shallow harbor all but unnavigable and, built on a malarial swamp, the climate could be deadly. In short, as Galvea's secretary, Juan Manuel Viniegra, recorded, San Blas 'is a lmast unintabitable as a consequence of its scorching 
climate and the hast of poisonous insects jittering its soil.,:2

On the other hand, well-sheltered and considerably north of the port of Acapulco, San Elas strategically provided a shorter, mare direct route to northern waters. This factor assumed considerable importance when even from San Blas a voyage to the cape of Baja California in a schooner might consume as many as twenty days; in a smaller packet-boat nearly three months might be required. $z=$ Conveniently situated only a short distance from the supply and provincial capital of Guadalajara, naval department personnel might be quartered at nearby Tepic, a community in the mountains Alexander von Humboldt later described as "salubriqus". 2a Finally, a good, local supply of stipbuilding timber tipped the balance in San Elas's favor.z-

$=1$ Cited in Thomas Vaughan, "Russian, French, Eritish and American Incursions into 'The Spanish Labe',' To the Totem Shore: The Spanish Presence on the Northwest Coast, Santiago Saavedra, gen. ed. Madrid: Ministerio de Turismo Y Transporte, 1586): 41 .

a Michael E. Thurman, The Nayal Department at San BIas. New Spain's Bastion for AIta California and Nootka, 1707 to 1798 (Glendale, Ca.: The Arthur H. Clarke Co., 1967) 53. By comparison, a modern crossing by government ferry from Puerto Valiarta to La Paz requires only about 24 hours.

sa Alexander von Humbaldt, Poljtical Essay on the kingdom of New Spain, trans. Jatin Black, val. 2 (New Yark: I. Riley, 1811) 149-50.

a Thurman, passim. For a first-hand account recorded in the early nineteentr, century, see Humboldt, passim. 


\section{NORTH TO MONTEREY}

Spanish fear of the Russians grew almost exponentially with each new revelation that the Euro-Asians edged ever closer to California. The Russians saw the area as part of their expanding Pacific empire, whereas the Spanish viewed the north coast as nathing more than an extension of Califarnia.zo Eut what resistance had any Russian fur-trader ever encauntered from the Spanish who alleged to "own'" it?" The answer is, none.

Dut af curiasity not unlite Spain's early search for the Strait of Anian Russian explorers sought to discover the geographical relationship between their empire and America. The Cassact: Semen Dezhnev, for example, first espied the Bering Sea (the true Northwest Passage) in 1648 when he led a party of ninety men alang the Russian coast until it met open sea. Dezhnev unfortunately shared a comman fate with the Spanish mariner Ullaa, because the information was neither utilized nor lang remembered, and credit for the discovery ultimately went to another, Vitus Eering, a Dane in the emplay af the Tsar.

After 1700 Peter the Great renewed Russian interest in Pacific exploration. Several impetuses lured fur-traders morth and east toward North America: to emulate other empires meant to explore and to exploit; to seek greater scientific knowledge; to accommodate the demands af "the 
youthful enthusiasm and dreams of the new Russian navy'"; and, to augment a dwindling supply of valuable pelts.zs Among the notable Russian explarers who stand out amang the many who visited the north-eastern shores of the 'Spanish Lake', are Bering, and Aleksei I. Chirikov. Although commercially profitless, Eering quite unwittingly led the cartographically successful First Kanchatka Expedition of 1725-1731 inta the strait that now bears his name. He alsa led the Secand Kamchatka Expeditian of $1733-1742$ but died after his ship wrecled on Bering Island. His second, Chiribov, managed to salvage the vestiges of the scurvywracked expedition, and completed the voyage--again to considerable cartographical effect. $¥>$

As their efforts clearly paid well in furs, Russian excursions ta Alaskan shores became mare frequent, and established the initial alien presence in the northeast Pacific that so frightened the Spaniards. The Spanish at length responded by settling Alta California. The effort began with a four-pranged thrust in 1768-E9, with two parties sailing and two marching overland. 20

\footnotetext{
ze Vaughan, "The Spanish Lake," 25.

2 Vaughan, 'The Spanish Lake," $26-28$. See also
} Chapters IV and $V$, "Discavery of Alasta,", and "Death of Eering," in Bancroft's ALaska, $35-E 2$, and E3-74, respectively.

20 See Chapter XVII, "The Spanish Occupation af Alta California," in Chapman's spanish Period, 216-231. 


\section{BEYOND CALIFORNIA}

Despite Spain's efforts in Califarnia reports of Russian meddling in mare northerly waters continued to circulate and startle the Spanish. Ey 1773 it had become clear that Spain would adopt additional measures in the "Lake" before being satisfied that its claims had been secured. Viceroy Antonio de Bucareli, who arrived in New Spain in 1771 after serving $s i x$ years as governor gf Cuba, received arders in 1773 to take further action to circumvent Russian meddling in the northern climes.

Indeed, by 1773 and the warnings issued by Spain's new ambassador to Russia, the Conde de Lacy, expeditians led by Eering's heirs had penetrated the Pacific Northwest littaral southward to 64 degrees North latitude. Further, the count speculated that Russians might invade California, 2ø and, to that end, Minister af the Indies Arriaga directed Bucareli immediately ta take steps to preclude such an event.

\section{APQCRYPHAL VOYAGES}

A final factor drawing the Spanish northward again after almast two hundred years af neglect were tales af imaginary voyages said to have discovered the Strait of Anian late in the sixteenth century. The first of three

z Mercedes Palau, "The Spanish Presence on the Northwest Coast Sea-going Expeditions (1774-1793), " To the Totem Shore: The Spanish Presense on the Northwest Coast, Santiago Saavedra, gen. ed., Madrid: Ministerio de Turismo Y Transporte, 1986): 43. 
significant stories is that af Lorenzo Ferrer Maldonado, published in 1609. He claimed to have traversed the strait in 1588 an a course which evokes a striking resemblance to the actual passage. Toward the end of his testimony Maldonado recorded:

Ta some persons it has seemed impossible to navigate at so high an altitude of the pole;--in answer it may be coserved that the Hanseatics I ive in latitude 72 degrees.. . Having cleared the strait af Labrador we begin to descend from that latitude, steering W.S.W. and S.W. for three hundred and fifty leagues, till we arrived in latitude 71 degrees, when we perceived a high coast without being able to discover whether it was a part of the continent or an island, but we remarked that if it was the continent it must be opposite to the coast of New Spain.

Maldonado's well earned reputation as an informed member of the nautical fraternity buttressed his claim. 91

The second, and certainly more infamous apocryphal voyage sailed under tre command af Juan de Fuca, alleged discoverer af the straits that now bear his name. Although not officially publistied until leze the fuca tale may have influenced the voyages of Cermento in 1594 and Vizcaino in 1596 and 1602, as noted in Chapter I. Raised by Professor Warren Cool, this interesting case considers several factars.

First, in building a plausible argument far Fuca's tale Cocil: argues that if Fuca cactually a Greel: baptiaed

Do Lorrenzo Ferrer Maldonado, Appendix No. I I, A Chronological History of loyages into the Aretic Regions, by John Earrow, 1873 (New York: Earnes and Noble, 1971) 28.

01 Cooli, 21 . 
Apostolos Valerianos? in fact had convinced Spanish

authorities that he had found the passageway, both Cermentio and Viacaino would surely have been privy to the information by virtue of their positians in New Spain. If authorities believed Fuca's tale to be true then it helps explain the flurry of activity an the coast in the periad $1592-1602$. Moreover, as noted, Spain decided to forego further explorations in part because of the fear that interlopers would exploit the passage. This makes more sense, obviously, if colonial officials held the existence of the passageway to be a demonstrated fact. $a x$ Nanetheless, Cook is ultimately non-committal. He writes:

While it is probable that fuca was an experienced pilot in Pacific waters, there is no corrobaration that he led an expedition to a high altitude in 1592. Yet the absence of confirmation of such a voyage does not remove it from the realm of the possible... The archives of Spain and Spanish America are far from plumbed and may yet provide evidence to prove or disprave Fuca's claim. oa

Wagner, however, from whom Coul: borraws heavily, gives the veracity of Fuca's claim na credence, charging, "there is no prabability whatever that fuca or anyane else had discovered this strait.', m-4

Unquestionably, however, the publistied claim played a role in launching the expeditions af the 1770's. Michael

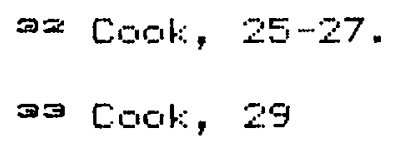

34 Henry R. Wagner, introduction, "Fray Benito de la Sierra's Account of the Hezeta Expedition to the Northwest Caast in 1775," trans by A.J. Eaker, CaIjfornia Historical Societ.y Quarterly 9 (1930): 208 . 
Lok, financial backer of Martin Frobisher's voyages in 1576 , 1577, and 1578, met Fuca in Venice in 1596, and fram him recorded a remarkable tale:

... a broad Inlet of Sea, between 47 . and 48 . degrees of Latitude: hee entred thereinto, sayling therein more than twentie dayes, and found that land tending still North-west and North-east, and North, and also east and South-eastward, and very much braader sea than was at the said entrance...

Wagner gives considerable weight to the influence of the third alleged vayage through the Northwest Passage, captained by Bartholomew de Fante in 1640. Published without fanfare in London in 1708 this tale, in canjunction with the Maldonado and Fuca legends, helped persuade the Eritish House of Commans in 1744 to post a 20,000 pound reward for anyone who could verifiably re-find the passageway. as Not surprisingly, tris act did not go unnoticed in Spain, although several. decades would pass before the Iberian nation would be moved to action.

It may be abserved that the various influences prompting the 1770 's expeditions essentially mirrored the impetuses behind the vayages of the late sixteenth and early seventeenth centuries. Dbviausly, however, their respective weights had changed. While it may be held as axiomatic that always a lust for riches and adventure fueled the actual vayagers, this proved to be less true for colonial officials

9 Coot:, 540. A full transcription of Michael Lot:"s Fuca tale is presented in Cook, 539-43.

ae Coukt, 30. 
in the late eighteenth century than it had been in the sixteenth century.

The Crown sought first to protect territory it considered to be unequivocally Spanish, and that specifically entailed defense against encraachments by Russians, Britons, interlopers, or any potentially disruptive agent(s). As a corollary to this a desire to find the Strait of Anian re-surfaced. As it had been demanstrated to official Spanish satisfactian in the sixteenth century that no easily accessible source of wealth could be gained from the north coast and hence no compelling economic mative to continue searching the coast existed, it was equally true that Spain's New World Pacific shares were vulnerable if such a passage could be found. As a result, Spain felt that no discavery better served its interests tran a well publicized discovery; but, conversely, if locating the passage was inevitable then Spain logically wanted to arrive first. $\rightarrow$ Similarly, alleged voyages of the late sixteenth and early seventeenth centuries and an intense British desire to find the Strait of Anian alsa served to sparl: the new Spanish interest in Pacific Northwest exploration and exploitation. 


\section{CHAPTER I I I}

\section{UNDER BUCARELI'S DIRECTION}

Placed in an eighteenth century context, the reemergence of the various sixteenth century impetuses behind the Spanish voyages to the northwest coast led to the deployment of new expeditians in the 1770's. Spanish fears, especially of Russian encraachments into the Pacific Northwest, festered early in the decade, forcing Spain to react. Viceroy Bucareli surveyed and directed plans to thwart the perceived foreign threats, and to establish a definitive, legally tenable Spanish claim to the littoral. Antonio Maria Eucareli y Ursua, the 4Eth viceroy of New Spain, arrived at the port af Veracruz August 23, 1771 , ready to take up his new duties. Althaugh his transfer from cuba disappointed the deeply conservative viceroy, Bucareli's character was such that he embraced duty as a passion. 1 His energies, as a result, ensured a cordial relationship with the hard-worling visitador, Jase de Galvez, who stayed on several months after Bucareli's arrival. to familiarize the new viceroy with the workings of

- Eucareli wanted to return to Spain in 1770. "Five years is as much as a man can serve well in America,", he wrote to a friend. Cited in Eobb, 20 . 
colonial administration and the efforts he had made to improve them.

Eucareli's biographer, Eernard Eobb, attributes the viceray's initial hesitancy in affice ta a typically cautious attitude magnified by unfamiliar surroundings. 2 As with his predecessor Carlos Francisco de Croix, the new viceroy faced hostile Indians an the northern frontier, a meager budget with which to administer the colony, and pressures to increase revenues for the mather country. Still, many authors have heralded his successes. He balanced an endemically unbalanced budget, $\rightrightarrows$ and oversaw some of New Spain's mast productive years as the world's largest producer of silver. 4

Bucareli abtained full awareness of earlier warnings about Russian designs on the northwest coast, possibly an Califarnia. Until 1773, however, no action he took impacted on the new California settlements or arose from the biowledge that Russians might attempt to overrun the outposts. Several views attempt ta explain the viceroy's apparent inertia. Noted scholar Charles Edward Chapman

\section{$=$ Embb, 131 .}

- Eobb singles out Eucareli's financial wizardry as his greatest achievement. However, he stresses that no fundamental rearganization or re-structuring of the calony cccurred during Eucareli's tenure; rather, in good Elurbon fashion the viceroy simply tightened lax adherence to regulation. Babb also insists Galvez should share in this glory. See Erabb, 209-11.

* See Eubb's chapter, "The Mexican Mining Industry," $172-204$ 
writing in the 1920's calls Bucareli 'the greatest hero who has ever appeared in the field of California history,", and argued that the viceroy simply needed a settling-in period at his new past before his greatness could blassam. $=$ But ane must be cautious with Chapman's opinions, for he later marshalls evidence of a very questionable nature. For example, to complement his glowing admiration af Bucareli, he writes: "One need anly glance at the full name and the titles [a tatal of 23 ] af the new viceroy to realize that he was a man of mare than ordinary distinction."

Professor John Caughey observes several factors influencing the viceray. First, he says, the viceroy's simple ignorance of the situation changed when Fray Junipero Serra, president of the Califurnia missians, visited Mexico City in 1773 and beseeched Eucareli for support. Serra's plea maved the deeply pious man viceroy. Second, he cites Captain Juan Bautista de Anza's proposal to secure an coverland route to the Califarnia missians as influential. Third, Caughey argues, perhaps "most influential was his (Eucareli's) realization af the strategic value of the Spanish outposts in California,"

Eobb, whose biography of the viceroy is nat unkind, scoffs at both Chapman and Caughey's assertions, charging "the projects",--and he includes Anza's expeditions--" "did

- Chapman, Spanish Period, 242.

- Chapman, Spanish Period, 2E9.

7 Caughey, 137-38. See also Eobb, $162-63$. 
not originate with the viceroy", at all. "In fact, during his entire viceregency Don Antanio was the source of very few original concepts." Bobb argues that Eucareli did little mare than follow arders from spain or take action on the suggestions of Galvez.s Most recent scholarship generally accepts Bobb's conclusion. California historian C. Alan Hutchinsan, for example, suggests that "official" hands almost exclusively guided Bucareli's actions.10 Neverttieless, when in 1773 new reports of Russian encroachments arrived from Spain it was Viceroy Bucareli who signed the arders sending an expeditian north.

\section{THE JUAN PEREZ EXPEDITION}

In July of 1773 Eucareli instructed Juan Perez, chief navigator at San Blas, to draw up and submit plans for an expedition to reconnoiter the northwest caast. Chasen specifically because he had the most experience of any in the department, Perez had been stationed at San Blas since 1767. Although he never rose higher in station than the rant: af ensign (pilat first-class) Perez, recarded Bucareli, was - the only person with sufficient experience and service in the Department of San Blas to undertake the commission.",11

Eabb, $1 E 4$.

Babb, 270 .

10 C. Alan Hutchinson, Fmontier settlement in Califormia, 1769-1835 (New Haven: Yale University Press, 1969) 1-43. See also Richman, E2-89, and Cook, 41-84.

11 Bucareli to Arriaga. Cited in Thurman, 78-7ヨ. 
A veteran of the Manila Galleon service, Perez piloted one of the initial vessels to visit Monterey in 176B-6G. He was also the first spaniard of the eighteenth century to enter both the port of Manterey and the port of San Diego. Additionally, according to ane account, he saved the Alta California missians from imminent starvation in 1770.12 Perez's detailed plans demanstrated a thorough ronowledge of the Pacific. Four central points can be delineated: the vayage should be undertaken in the newly constructed frigate Santiago; the voyage should be launched in eittier December, January, or February; a year's supplies should be taken; and, crew members should be recruited in part from the California presidias.13 Eucareli, in turn, then relayed his proposals to Minister Julian de Arriaga in Madrid. Upan learning of the plans Carlos II ordered the assignment of six new naval officers and a new pilot to san Elas, and gave full support to the Perez expedition.

Perez received secret arders December 24,1773 , directing him "to ascend to the latitude which he considers suitable, keeping in mind that the landing is to be made at Eo degrees of latitude." He was then to reconnaiter the coast, "never lasing sight of it," and to explore it as opportunity presented itself without, however, attempting any permanent settlement; and, as landings occurred

1 a Donald C. Cutter, ed., Tha California Coast: A Eilingual Edition of Documents from the Sutro Collection (Norman: University of of:lahoma Press, 1969 ) xvii. 
possessian was to be taken in the name of Carlos III with a cross being erected beneath which a buried bottle would contain supporting documentation.

In the event that fareign settlements be detected, Perez should avoid contact and sail north to accomplish his duties. Were contact with foreigners unavoidable he should canceal the purpose af the vayage. The expedition was also charged with investigating the commercial potential of the north, to search far 'spices, drugs or aromatics, wheat, barley, corn, beans, chick-peas....precicus stones or articles which our nation cansiders valuable.' 14 Indians were to be treated kindly if encountered: six-hundred fortyeight bundles of beads and cloth were included for the purpose of ensuring good relations with the native Americans. Finally, Bucareli instructed Perez to deliver provisions to Manterey. $1=$

At midnight January 24,1774 , the Santiago set sail with a crew of BE.1 1 In keeping with narmal practise the vessel launched itself well inta the Pacific ta avoid relentless southwest acean currents. To sail north meant, in effect, to veer in a wide arc generally northwest then

14 Manuel P. Servin, trans., "The Instructions of Viceray Eucareli to Ensign Juan Perez." California Historical Society euartarly 40 (1961): 240-41.

2 Servin, 239

$1=$ Eucareli was tool no chances that illness or other deprivation might waylay the intentions af the Crown--the ship's complement registered fully twenty-two mare than capacity. Thurman, 127-28. 
follow the acean currents southward along the coast. Despite arders not to stop until Monterey (and there only briefly) Perez lay anchor in San Diego in mid-March to repair a leat: sprung in the hull.17 While Fray Serra disembarked March 13, the vessel only turned north again April 5 . On May 8 the Santiago landed at Monterey to unload supplies where the expedition's two chaplains, Fray Tomas de la Pena and Fray Juan Crespi, came aboard.

After another month-long layover the vessel set to sea June 11, but calm seas prevailed for weels and the expedition made scant progress until July. Edging ever northward, the prevailing weather brought rain, fog, and increasingly cold temperatures. Fray Pena recorded a typical entry in his July diary:

At dawn on the thirteenth the wind continued at west-narthwest, although it was not so strang, and the sky was clear as during the night, but at seven a'clock it was overcast again. At mogn it cleared, and the navigating officers got an observation in 48 degrees 55 minutes narth laticude... During the afternown the sky became avercast again. About seven o'clock the wind hauled to the soutriwest, very fresh, and the course was changed to the northwest. At that hour so thick a fog came on that barely the prow of the stip could be seen and it was so wet that it seemed to be raining. Thus it continued...1日

Dn the 15th Perez decided ta steer toward the coast with the intention of making a necessary landing to replenist, dwindling water supplies.19 The voyage continued,

\footnotetext{
$1>$ Thisman, 128.

te Servin, trans. 151.

x Palau, 4E.
} 
then, sighting and baptizing the Queen Charlotte Islands in the name Santa Margarita. Native-Americans engaged the voyagers in friendly, if unintelligible, discourse and, although only two saw fit to board the vessel, surrounded the santiago at one point with 21 canoes.20 Finally, at a North latitude of 55 degrees Perez, having failed to land anywhere on the coast and take possession in the name of the Crown as instructed, turned the santiago around and headed south.

On Alugust 8, 1774, the santiago dropped anchor off Nootta Sound, "a place which it seemed ideal to claim." Indians paddled aut in large canoes and eagerly traded with the Spanish sailors. Forthwith, the ensign organized and launctied a shore party, but, he recorded in his journal:
As I was preparing to set out for land, the West wind suddenly arose sa fiercely that in an instant the sea swelled in such a way as to cause alarm. The anchorage, which extended four or five leagues cut to sea, was unlevel, and the wind such to perturb the sea. In the light of this unexpected accurrence, and the fact that the frigate was dragging the anchor and heading rapidly onto the coast, I deemed it necessary to cut the cable and set sail lest we all perist.:

Continuing, the voyage encountered nine weets of miserable weather and, as scurvy ravaged the crew, on September 27 the Santiago at last cast anchor at Monterey. After a recuperative layover the vessel left port october $\exists$ and Perez and his crew landed safely at San Blas November 3.

ac Eancraft, Northosest coast, 154.

2 Cited in Palau, 4E. 
The ensign immediately forwarded the ship's logs to Bucareli in Mexico City, apologizing for taving not fully completed the orders given him. Eucareli nonetheless congratulated Perez for "although everything desired and planned for had not been achieved, the information obtained was af value and extended knowledge to an extent which would make sailing to higher latitudes easier.'"2z Eucareli expressed similar sentiments to Minister Arriaga in Madrid, and noted immediate plans for a secand voyage--an expedition that Perez would not lead, but wauld instead be relegated to secand-in-command of the pilot vessel.

\section{THE HEZETA EXPEDITION}

Lieutenant Brung de Hezeta and five other afficers despatched from Spain to San Elas by Carlos II I arrived at the naval department in the early fall af 1775 . Bucareli commissicined Hezeta to lead the three-vessel expeditian, the instructions for which largely duplicated those given to Perez exicept that a latitude of 65 degrees North rather than EO was squght. The second vessel, the schooner felicidad (more commonly known by its alias, Sonora) would be captained by Juan de Ayala, seconded by Juan Francisco de la Eodega y Quadra, and steered by Antrinio Moureile.za

\footnotetext{
za Cited in Palau, 47.

za Mouriting just two sails and scarcely 36 feet in
} length, the secand vessel gave the expedition three added capabilities: to be able to explore the shallow details of the coast where the larger stip could not enter; to add maneuverability in tight spots where the vessels had been 
Accompanying the larger vessels the packet-baat san Carlos, captained by Miguel Manrique and seconded by Jose de Canziares, had arders to break off and explore San Francisco Eay.

Almost immediately after the vessels set to sea March 1E, Manrique went quite mad. Imagining his person to be in considerable danger, he armed himself with any number of pistols to ward off would-be assassins. Having brought the situation under control. Hezeta transferred Ayala to the San Carlos to take over Manrique's command and returned the unfortunate officer to San Elas, temporarily delaying the missian. In Ayala's absence command af the sonora fell to Eodega; and the vessels were re-launched from San Blas March 19.

Progress proved fitful. Although the San Carlos brake away March ż to explore San Francisco Bay, contrary weather actuajly blew the vessels south of the latitude of San Blas, and not until late May did they pass the latitude of Manterey. In early June the expedition dropped anchar at Trinidad Bay, California, at North latitude 41 degrees 03 minutes, roughly between Caper Mendacino and Cape Elanco. And an June 11 a shore party took possession in the prescribed manner. Amongst a crowd of seamen and friendly nativeAmericans, Fray Palou recorded:

...the Father preacher Fray Miguel. de la Campa sang the Mass, during which many of those who had 
landed took communion. In the Mass the father gave his talk, exhorting them all to continue the voyage cheerfully until the desired purpose should be attained. $z-4$

Additionally, the crew erected a cross and beneath it buried a bottle with attendant documentation.

July 13, 1775, the vessels dropped anchor near point Grenville, Washington. The flagship's crew engaged the native-Americans in friendly discourse, trading and bartering, while the schagner some miles narth launitied a shore party to find frest water. The six sailors Eadega deployed on shore were caught unawares by hostile Indians and 'torn in pieces,", as was the launch. $z=$ In retaliation Erodega's crew copened fire on some of the Indians' canoes near the ship, and lililed several of the accupants. Badega wanted to deploy a larger shore party to exact a more substantive vengeance but a council of the expedition's officers dissuaded him.

The council also discussed the advisability of sending the Sonora back: to Monterey because of her small size--but Eadega and Mourelle insisted on campleting their missicun. Said Bodega of his vessel:

...there is no hiding her small size, bad steering, frailty, slowness, and the fact that I am forced to give more sail than should be necessary. All these reascins...should have been braught to his Excellency's notice by those responsible, informing him of the danger her

24 From the journal of Fray Palou. Cited in Thurman, 153 
attributes constitute. However, what is done is done, and no fear will stand in our way. ze

Setting out to sea directly westward on the 14 th, by the

$19 t h$ Perez advised that because of sickness (scurvy), ill

winds, and given the lateness of the seasan, the expeditian

turn southward. Again, Bodega and Mourelle protested, and

Hezeta, relenting to their pressure, ordered the expedition

to continue.

Then, as is perhaps well known, in the pitch of night

July 31 the schooner and her flagship separated. Mourelle

recarded:

On the 31 st it continued to be so darl that even during the day we could not see the frigate.

On the 1st af August at day-breal we had the same darl: weather, so that we could not distinguish at half a league's distance, nor had we sight of the frigate: we kept on hawever...27

Bodega apparently wasted no time in determining the

Songra's course of action:

At dawn... I resolved, in pursuance of my instructions, to continue the explorations alone, even though I took into consideration the advanced season, and the shortage of water.zo

26 Cited in Palau, 50.

$\Rightarrow$ Mourelle, Francisca Antanio, "Journal of a Voyage in 1775," Trans by Daines Earringtan. Voyage of the Sonora in the second EucareIi Expedition to Explore the Northrest. Coast. . 1775 by Daines Garrington CSan Francis60, 1920) 501.

20 Juan Francisca de la Eodega y Quadra, Expeditions in the Years 1775 and 1779 towards the West Coast of North America, trans. G.F Earwich: CPravincial Archives of Eritish Columbia, Victoria, B.C.) 3-4. 
Also within hours of the parting, at latitude 46 degrees 42 minutes North, the officers on the Santiago decided to head south far the very reasons earlier complained af by Perez. First sailing north ta 49 degrees 30 minutes-- 'in the regian of Nogtka," --the Santiago turned southward following the shore.z On August 17 Hezeta became the first European to espy the Columbia River. Cantinuing, the vessel at length entered the harbor at Monterey August 29 , and put astiore 35 men afflicted with scurvy, ane of wham did not survive.

EGdega meanwhile, apparently with full support fram his crew continued northward, reaching a North latitude of 58 eight degrees on two accasians, and taking possessian twice in the name of the Spanish Crown. September 8 , with a crew so wracked by scurvy that mast were functionally incapable of carrying aut their duties, the tiny vessel headed scuth. Recorded Elodega:

\footnotetext{
-. seven men were discovered with scurvy, some at the mouth and others with various pains which impeded the movement of their legs, from which circumstances there remained only two men in each watch, one of whom was indispensable for handing the rudder.

... I knew it would be impossible even trough I exerted myself to sail further narth to a higher latitude. And even the return trip would be doubtful if the winds freshened vigargusly, seeing we did not have enough men to handle the ship, and therefore I resalved to return... reconnoitering the coast whenever I found it possible. ac
}

zo Eancroft, Northwest Coast, 162 .

so Cited in Thurman, 160. See also Mourelle's account in Earringtan, 511-12. 
Conditians on board so deteriarated because of the sickness that both Eodega and Mourelle found it necessary to pitch in and help with the necessary, mundane sailing chores just to lieep the stip afloat.

After reaching Monterey october 7, and as soon as the men had sufficiently recovered, both vessels left far San Blas. On November 10, just two days out of Monterey, Juan Perez died.

\section{ARTEAGA AND BODEGA}

Even before the Heaeta expedition had returned to San Elas, Eucareli busily planned another foray. He directed Lieutenant Ignacig Arteaga and Francisco Hijosa, shipping master at San Blas, to draw up plans including provisions for fully arming the next expedition. Internatianal events, however, temporarily sidelined the project. The revolution in Eritain's American colonies drew both France and Spain's attention elsewhere, and Madrid indefinitely postponed the next expedition.

The northwest coast, however, received ather visitors in the Spanish absence. In search of the elusive strait af Anian, and following arders very much lite thase of Juan Perez, in the early spring of 1778 Great Eritain's illustrious Captain James Coak reconnoitered the northwest coast. Directed to survey the coast between 45 degrees and ES degrees Narth latitude, to avoid any Spanish settlements, and, fully aware of the 20,000 pound reward far finding the 
northwest passage, to take possession in the name of the

Eritish Crown wherever possible. 31 Importantly, he landed at Nogtka Saund, and his crew conducted considerable trade with the Indians there. Although Coat: did not survive his third famous voyage, his published journals appeared in Europe in 1784 to considerable effect, and in marked contrast with the secrecy of Spanish expeditions.

Ey 1778 Eucareli's plans for another Spanish expeditian resumed. Two new frigates were stocked and readied for service, with Arteaga leading the expedition from the flagship Pringesa, seconded by Lieltenant Fernandez Quirss, and with Eodega and Mourelle occupying similar positions on the second vesse1, the Favorita. On February 11, 1779, the expedition sailed, the Princesa with a crew af 98 and the Favorita with 100 . Instructians again largely duplicated thase given to Perez, with two exceptians. First, Bucareli Grdered the heavily armed expedition to attain a North latitude of 70 degrees; and, second, to arrest James Cook, if encountered.

Sailing north, and not nearing the coast until Alaska, the vessels did not land between 42 degrees and 55 degrees North latitude, and they visited California only on the route south. The vessels dropped anchar off the Alastan coast in early May where a landing party gathered water,

g1 Bancraft, Northwest Coast, 168-69. See also Barry M. Gough, "The Northwest Coast in Late Eighteenth Century Eritish Expansion,' Western Shore, ed. Thomas Vaughan (Portland: Dregon Historical Society, 1576) 52-53. 
fireword and ballast. From there the crews mapped shores, inlets and bays, and took possession in the name of carlos III. While the native-Americans received friendly treatment, Arteaga and Bodega took precautions to avoid a recurrence of the massacre during the Hezeta expedition.

The expedition also gathered much valuable ethnographic information, as Badega noted in his journal:

They cover their heads with hats well woven from the inner bark of a tree, and shaped like a funnel. On their wrists they wear bracelets of copper, iron, or whalebone, and on their nect: sundry rows of the beads they make of bone, and ears, twisted wires of the same metal, jet beads, and certain little globules from a gum, which resemble topazes. $9:$

The expedition again encountered native-Americans at the most northerly point reached, EO degrees 13 minutes.

Ey the end of July an old nemesis--scurvy--had afflicted yet another expeditian and 50 it tog turned toward the south, despite Budega's protestations. The vessels drifted apart before meeting again at Trinidad Bay, California, and continued from there on to san Francisco for a six weel: recuperative stop. The layover ended abruptly when a courier brought news of war between Spain and Britain and of Viceroy Bucareli's death.

Spanish officials strove to establish a tenable presence an the northwest coast in the 1770\% 5 . As tie received arders and warnings from his superigrs viceroy Eucareli arganized and directed New Spain's efforts. Juan 
Perez in 1774 recannaitered the narthern shares, but never landed ar toak passession. The following year Egdega sailed to the Alastian pantiandle and toot: possessian at several locations, while Hezeta, the expedition leader, at lower latitudes tools possession and became the first non-Indian to espy the Columbia River. Under Arteaga and Bodega's leaderstip, the last Eucareli directed expedition in 1779 explared the coast of Alaska in some detail, and took: possession in the name of the Crown at several locations. Spain obvigusly wanted a territorial claim to the morthwest coast that would be respected by its rivals. Given the expeditians' instructians, in Spain's estimation possessian-taking clearly granted the legitimacy sought. Nat surprisingly then, histary dwells an the success of possessign-taking as the unit by which to measure the success of the three expeditions. 


\section{CHAPTER IV}

\section{MEASURING SULCESS}

The significance and accomplishments of the voyages of Perez, Hezeta and Bodega, and Arteaga and Eodega have stimulated discussion among scholars. This takes into account more than successfully charting an island or a piece of coastline cnot that such actions are considered unimportant per se). For example, Viceroy Bucareli charged these voyagers with specific instructions. How successfully did the mariners complete their appointed tasks? Did the relative success of a given expedition much matter; and, to the extent that it did (ar did nat), what are the terms used to define it?

History judges these men within two general contexts, two sets of terms. The most fundamental yet easily overlogked criterian far the histarian is the cultural weltanschauung af which he or she is a part, and success is accordingly defined in these terms. This is af course necessary in arder for a work to be relevant to readers who, after all, also comprise a part of the same general warldview. Eut it is not enough. The principle of "scholarly detachment", should always apply ta research and analysis. Qne should attempt to distance aneself from the subject of study and then came to some "abjective", 
conclusion about it. Obviausly, all but the most vain

understand the inherent contradiction: the simple selection of a topic is itself a prejudiced decisian. As William H.

McNeil nated in his 1986 presidential address to the

American Historical Association:

.. the arrangement of facts to make histary

invalv[es] subjective judgements and intellectual

choices that ha[ve] little or nothing to do with

source criticism, scientific or otherwise. 1

This is not to suggest that history is neither warth writing nor reading, but, rather, that one must approach it with a critical eye, ever on the lookout for lapses in logic, bias, and 50 on.

This notian presages the second context in which historians have evaluated Perez, Hezeta, Eodega, and Arteaga; that is, the histarian's attempt to understand an event as it had been understood by those living when it gccurred. It is not the intentian of this paper to digress into a lecture on the merits of historiographical study, but only to set the particular terms of this chapter af enquiry.

Alj. the authoritative accounts of the Eucareli-directed voyages fall into the category of attempted ischolarly detachment." Dne might argue this is so quite by definition; after all, clearly none of the authors knowingly expressed a biased apinion thought to be anything other than the truth, i.e., a factual representation of reality.

1 William H. McNeil, Mythistary, or Truth, Myth, History, and Histarians." Amemican Histomical Review 91 (1986): 1 . 
Appropriately, the respective judgements granted Perez, Hezeta, Bodega, and Arteaga in history vary.

\section{WHITHER JUAN PEREZ}

Ensign Perea's place in history has remained largely static and not especially flattering to the Mallorcan mariner. Generally portrayed as an unforceful character lacting in fundamental courage, he has been roundly condemned. The particular charges against him are essentially two, the more serious of which stems from his failure to land anywhere on the coast and tate possession for the Spanish Crown as ordered by Viceroy Bucareli. Additianally damning, Perez decided to turn back toward san Elas rather than pressing ahead to 60 degrees North latitude, again as instructed.

To understand the significance of the ensign's failure to take passession one must appreciate the encirmous importance Spain attached to the ritual. Without the declaration of formal awnerstip derived from the traditional formulary, Spain of necessity had to concede that these lands were open to all comers. Thus, to effectively circumvent foreign encraachments an the caast, Bucareli instructed Perez and his successars to take possession, that is, to declare ownership.

Yet at the same time, official Spanish preoccupation with the ritual staod in a dialectical relationship to legal precedent. The 1670 Treaty of Madrid, penned by Spain and 
Eritain, recognized cwnership of colonial posessions in the New World derived by uti possidetis, that is, by effective accupation. = Article Seven of the treaty read:

The Most Serene King of Great Britain (Charles II) and his heirs and successars shall enjoy, have and possess in perpetuity, with full right of sovereignty, ownership and passessian, all the lands, provinces, islands, colanies and daminions situated in the west Indies or in any part of America, which said King of Great Britain and his subjects have and possess at present. 9

The treaty clearly acknowledged what Britain and other nonCatholic European nations had long argued, that gccupation determined ownership. 4 The issue with regard to the northwest littoral, however, proved to be intractable, in spite of the Madrid agreement.

As noted, Spain, via Eucareli's instructians, continued to believe that successful application of the ritual would legally protect its "possessions." Paradoxically, Britain too acknowledged the intierent legality of the formulary, the Treaty of Madrid--and uti possidetis--notwithstanding. James Coat:" 1776 orders, in part, read:

You are...to take possession, in the name of the king of Great Britain, of convenient situations in such countries as you may discaver... by setting up proper marks and inscriptions, as first discoverers and possessors. $=$

2 Cookt, 47, 152.

- Gordon Ireland, Eoundamies, Possessions, and Confliats in Centmal and North America and the Caribbean (Cambridge: Harvard University Press, 1941 ) 120.

* Gearge Woadcock, "Captain Cook at Noatka: The Political Aftermath," Histomy Today 28 (1978): 98. 
As should be readily apparent, Bucareli's instructions to Perez were at best legally ambiguous. While the formulary obviously held great importance for the Spaniards, it had been--at least technically--supplanted a hundred years earlier. Yet Britain also continued to respect the premise of the formulary, as demanstrated by Coof's arders.

Wagner dates the practice of ritualized Iberian possession-taking to late fifteentt century Partuguese voyages to the west caast af Africa.s In following the course of the farmulary's evolution, tie finds it tiad became common practise for the Spanist by 1500. What might consummate the act in the sixteenth century included cutting trees, gathering water, piling stones in a distinctive mound-shape, and, especially, erecting crosses beneath which both bottles with documentation inside would be buried and mass wiuld be said.

Upon discavering the Pacific Ocean's eastern share in 1513 Ealboa heaped stanes into the shape of an altar, inscribed the Crown's name upon it, and cut trees such that they might be easily visible, to demonstrate spanish Gwnership. Ealboa is often misrepresented as having taken possessian of the whole coast for Spain. This is clearly errcinedus, otherwise Spain need never have concerned itself

- Cited in Woadcoct, 97 . See also Manuel Servin, "Religious Aspects of Symbolic Acts af Sovereignty." The $A m a n i c a s 13(1957): 2 E 3-E 4$.

e Unless otherwise noted the bull: of the following information has been taken from Henry R. Wagner, "The Creation of Rights of Sovereignty through Symbolic Acts.", Pacifio Historical Review 7 (1938): 297-327. 
with Bucareli's possessian-taking instructians given to

Perez and others. Here or elsewhere, native-Americans witnessing the act would have had a requerimientor of sorts read to them with the intended effect to establish a basis for the Spanish claim. As should be apparent, these rituals symbolized more permanent actions that might be taken, such as establishing a settlement. Notably, officers took actians to attempt to ensure the crosses remained unmolested by the native-Americans, aften to little effect.

By the 1770's Spanish colanial officials had developed an elaborate formula for possession-tating, and fully onethird of Bucareli's instructions ta Perez focused specifically on this symbolic action. The order read in part:

In a loud voice he [Perez] said that in the name of His Majesty the king, Don Carlos II , Our Savereign (whom may Gad Dur Lord keep for many years...) he, as captain of the frigate and by

- The requerimiento was the declaratian Spanish afficers were required to read to the Indians before engaging them in battle. It consisted largely of affering not to make war provided the native Americans agreed to embrace the Catholic faith as the one True Religion. In practise, however, the Spaniards often read the requerimiento out of earshot, in the darl of night, or after a battle had been waged. Additionally, even if read in the prescribed manner the native-Americans could scarcely have begun to understand Spanish or Latin. See Haring, E. See also Lewis Hanke. Aristotie and the American Indians (Chicago: Henry Regnery Company, 1959) 1E-18.

* The Iberians had no monopoly on ritualized possessian-taking. Martin Frobister followed a similar formula in Canada's north, as did Jaques Cartier in Quebec, and Sir Francis Dral:e un the narthwest coast. These sailars also erected crosses (Drale left a plaque) and read a declaration in the name of their respective potentates. wagner, "The Creation af Rights," 30E-08. 
virtue of the arder and instructians which in the royal name were given to tijm by the aforesaid Most Excellent Viceroy of New Spain [Eucareli], was tating and toot possession, was seizing and seized possessian of this land. . Which he has discovered forever and ever in the said name of the Royal Crown... as its own property...by reason of the Donation and Bull of the Very Holy Father

Alexander VI... given at Rome on May 4 of the year 1473.9

Eucareli also instructed Perez to erect a cross transparted from San Elas, and to bury beneath it a bottle which housed papers testifying to the veracity af the claim. Finally, the orders directed the ship's chaplains to say mass, and lead the sailors in hymn.10

Despite the fact that in the late eighteenth century-as in the late twentieth--might aften determined right in internatianal disputes, Spain undeniably felt it stord on solid ground with regard to possessign gained by such means.1 As earlier noted, primarily the fear of Russian encroachments engendered the Perez expeditian. Thus, without immediate plans for settlement, the success of an expeditian--indeed, the success af Spain's general plan to manopolize mare than 2,000 miles af shareline and the

Gervin, 244-45.

10 It should be noted that na such possessian-taking accurred in California. It was not necessary, given the establistiment of the missians. Wagner, "The Creation of Rights,' 31.1 .

11 Allusion is made specifically to the Nootka Sound contraversy of the mid-1790's between Spain and Eritain from which spain came away empty handed not so much because Eritain disputed the Spanish claim on legal grounds-altuugh it did, ostensibly--as that spain dared not rist: war with its more powerful. rival. See Cook. 
unt: nown hinterland it sheltered--required strict adherence to Eucareli's carefully scripted instructions. Yet Perez failed to fulfill this most important af his arders. Why?

The one attempt Perez made to land and claim possession foundered off the upper west shore of Vancouver Island. By all. accounts the sudden squali that nearly swamped the Santiago precluded tating possession at Nogtta Sound, despite the attempted launch. Similarly, Perez's action in cutting loose the anchor line and heading out to sea is considered prudent. The question raised by mast scholars is not with this event as such but, instead, why no ather attempt to land occurred. The generally accepted conclusion can best be seen in light of Perez's decisian to turn south rather than to continue ta EO degrees Narth latitude. As noted, the ensign argued that dwindling water supplies and his crew's sictiness from scurvy farced tim to turn southward. Many scholars find these excuses inadequate and cowardly. Far others, however, Perez's stature remains largely untarnished by the decisian. Three worts based an the examination of primary evidence show an inclination to favor Perez. Loosely, it is fair to conclude that earlier texts, such as Eancroft's (1880's), favorably evaluate Perez, while the later worts, such as Coot:s (1973), almost without exceptian have candemned him.

Eancraft extals ensign Perez for the simple reasan that the expedition, despite its tectinical failure on several counts, brate new ground in history. Perez, he notes: 
.. though he had not reached latitude 60 degrees, as instructed, nor discovered any good ports, nor landed anywhere ta take possession for Spain, nor found either foreign establishment or proof af their non-existence, he had still gained the honor of having discovered practically the whole Northwest Coast. He had surveyed a large portion of the two great islands that make up the coast of Eritish Columbia, giving the first descriptian af the natives; he had seen and described, though vaguely and from a distance, nearly all of the Washington coast, and a large part of oregon. He had given to his nation whatever of credit and territorial claims may be fuunded on the mere act of first discovery. 12

In short, being first, quite by definition meant going where none (except Indians) had gane befare, thus history must recognize--and congratulate--the accomplishment.

The fattier of American borderlands fistory Herbert Eugene Eblton, whose assessment of Perez concurs with Eancraft's, on this count opines:

To the simple sailors with Perez the terrors of the uncharted North Pacific were no less real than thase which cowed the crews of columbus when he ventured across the mystericus sea of the west. To the officers assembled these seemed reasons enough for veering to the shore, even though they were nine wide degrees short of the goal marked on the map by the hard-driving Eucareli.1o

Clearly, both of these historians draw their primary measure of Perez from the fact that he was the first to go where none had gone before. Other evidence has been

1 a Eancroft, Nortivest. Coast, $156-57$.

13 Herbert Eugene Bolton, Fray Juan Crespi: Wissionary Expiorer on the Pacific Coast, 1769-1774. 1927. (New Yort: AMS Press, 1971; 1. Named chair af the histary department at the University of California, Eerleiey, in 1919, the following year Bolton was appointmented director of the Eancroft Library. See Jahn Francis Bannon, Herbert Eugens Eolton, The Historian and the Man, 1870-1953 (Tucsan: University of Arizana Press, 1978 ) xivi. 
marshalled to defend this approach. Balton, for example, cites bad weather as the real culprit in Perez's inability to land. 14 But he does not stap there; he would have Perez as a North Coast Odysseus stumped only by Fate in the pursuit of tis goal. $2=$ Bancroft, however, despite praising the ensign, also questions "Whether Perez made the best use of his opportunities..."16 But the illustrigus bool:seller is not striving to have it both ways, concluding, "Perez, a bold and experienced pilot, was a better judge thari I., 17 Chapman is also quick to laud Perez, but this ranting is derived tangentially. Chapman's wort: focuses an the history of California. To that end, Perez made genuine contributions: he led, for example, many supply runs from San Blas to the California presidias. From this valuable service Chapman's approach takes shape. He writes that Perez - was by far the most notable figure in the life of the province." 1e; and, that "mone had worled more faithfully and unassumingly far the good of the new establishments." 10

\footnotetext{
$1+$ Boltan 1vi.

$1=$ Boltan, Ivii.

16 Bancroft, Northwest Coast, 157.

17 Bancroft, Northwest Coast, 157 .

19 Chapman, Spanish Period, 276 . In 1915 Chapman earned
} his Ph.D at the University of Calitornia, Berbeley, under the tutelage of Herbert Eugene Balton. He subsequently taught history there until his death in 1941. See Eannon, $102,217-18$. 
Additianaliy, he accepts the bad weather argument endorsed by Eancroft and Boltan.zo

Where Chapman differs from the ather two Perez sympathizers is that his validation af the Mallorcan's worth derives from the psychological phenomenon of generalization. That is, Chapman appears predisposed to favorably evaluate Perez in all endeavors far his positive cantributions to early California histary. In a very real sense chapman's estimation of Perez is a logical non-sequitur because the canclusion does nat follow from the evidence. In fact, Chapman presents no evidence on this count, preferring instead to measure Perez by a criterion that does nat apply: how successfully the mariner perfarmed his duties as a captain af the Califarnia supply vessels is irrelevant visa-vis how well he performed as head of the 1774 expedition to the Northwest coast.

As ane of Perez's many detractors, Wagner was the earliest and most vociferous:

.. Iit was] a perfectly futile expeditian. The fact is that Perez was entirely too timid for worl: in these northern waters. No good reason existed for not going up to 60 degrees as ordered, and far not landing and taking possession, which was the real biject in sending him. $\neq 1$

The expedition, in other words, failed because ensign Perez proved altogether incapatile of fulfilling the prime

so See Bancroft, Northwest Coast, 154; and, Ealton, luJvi.

21 Wagner, "Sierra's Account," 204. As Wagner's writing was voluminous, such criticism can be found in many places. See also Wagner, cartography, 172-74. 
directive, and his defense for not following orders is untenable.

Lilewise, Michael Thurman blasts Perez for all the reasons wagner advances, but tis invective includes criticism far defying orders nat to stap anywhere before Monterey ctre montr-long layover in San Diego dio violate Bucareli's instructions), and suggests that the water shortage either was pre-meditated sat worst) or simply a sign of incompetence (at best). $=2$

Like Wagner and Thurman, Warren Cook chides the ensign for maling but one attempt to land; and like Thurman he says that Perez needlessly wasted time in San Diego. Eut Cook: goes even further, all but labeling the Mallorcan a coward. - Perer seems to have lacked in full measure the intrepid qualities requisite for meeting the challenges of tis mission,", the historian charges.za The invective continues, but for gur purposes this statement is especially important for another reason, because it hints at the very different apprach taken by the Perez-detractors vis-a-vis the Perezsympatiizers.

Cools, Thurman, Wagner, and athers who, based on the examination of primary documents, see in Perez failure rather than success, da so in large measure because of the achievements gained by subsequent expeditions.24 Cogl:"s

$=2$ Thurman, $131,138-40$.

$=\infty$ Cuat, 62 . 
comment is a veiled comparisan af Perez to Hezeta, Arteaga, and especially to Bodega, although names are not used as such. The Eancroft-Bolton approach can be tacitly disregarded as simplistic and narrow. Perez's firstdiscavery was meaningless legally, for all accounts tiere discussed recognize and accept the necessity of formal possessign-taking. And as every historical account stresses the singular importance of possession-taking, anything less in fact signaled failure. Later expeditionary successes buttress this canclusian. That is, the bad weather argument appears ludicrous, retrospectively, when later voyagers met and prevailed aver similar canditians withaut the benefit of greater--if not lesser, as was the case with Badega and Mourel le--rescurces.

Analyses of the Perez expedition based on primarysourced exist in short supply. Mare plentiful secondary analyses tend generally ta criticize the ensign.za In doing so they typically cite wagner, Thurman, and Coot:, as well as utilizing the respective expedition journals. of course,

24 See alsa Donald C. Cutter, "Spain and the Oregan Coast," Westemn Shore, ed. Thomas Vaughan (Portland: Oregun Historical Saciety, 1976) 28-4E; Barry M. Gough, Distant. Dominion, Britain and the Northwest Coast of North America, 1579-1805 (Vancolver: University of Eritish Columbia Press, 1980) 93-94; Derel Pethick, First Approaches to the Northwest Coast (Vancouver: J.J. Douglas Ltd., 1976) 43-44; and, Rictiman, 118.

$2=$ This includes four Masters theses: Mildred Delongchamp (1946), Tamas Eartroli (1960), Oakat, L. Janes (19E0), and Herbert k. Beals (1983--see the bibliggraphy af this paper for full citatians). Far a somewhat pedestrian presentation see Jahn Kendrick, The Men with Wooden Feet. (Toronta: NC Fress Limited, 1986) $3-26$. 
many accounts simply relay the "facts", without evaluating the relative success of the voyage. This is most typical af the peripheral accounts such as those af Bernard Bobb, John Caughey, and Robin Fistier. 26

Befare moving into a discussion of the Hezeta expedition it should be noted that at least one ather defense of Perez's actions has been raised. In a very short study of Perez's final days, James G. Caster suggests that an undetermined illness afflicted the mariner and might well have caused him to act in a "capricious" way, thus lending to a frame of mind that might disregard arders.z>

Finally, it is also instructive to note that several authors cite Perez's contemporaries as being rather critical af him. Bancroft, for example, notes Mourelle's 1791 allegation that Perea's performance bordered on the inexcusable. On a coastline that stymied the ensign subsequent voyagers visited many hospitable natural harbors, Mourelle complained. za More suggestive, yet equally telling, Eucareli's fulsome praise of the voyage, Barry Gough, among athers, interprets as evincing the viceray's "clear disappointment., , :20

as See citations for Robin Fisher, Caughey, and Eabb in the bibliograptiy of this paper.

a James G. Caster, "The Last Days of Juan Perez, The Mallarcan Mariner," Journal of the Hest 2 (19E3): 15-21.

2m Eancraft, Northosst Coast, 157.

$=$ Gough, Distant Dominion, 94 . 
In conclusion, Perez has been on balance, if nat exactly vilified, at least viewed with mild contempt. And, while the works here utilized are not exhaustive they represent the general corpus of work in English on the subject. To fully understand the context of the criticism, because much of the palemic stems from comparison with tis colleagues from the Naval Statian at San Blas, it is necessary to examine next the historical literature's treatment af the Hezeta and of the Arteaga expeditions, beginning with the farmer.

\section{HEZETA AND BODEGA, 1775}

Scholars unanimously extol the accomplishments of the Hezeta expedition. On virtually no caunt is the endeavor deemed anything less than a complete success far spanish interests. The credit, however, belongs not ta expeditian leader Bruno de Hezeta but to Juan Francisco de la Eodega $y$ Quadra and Antonid Mourelle, Bodega's second-in-command. Additionally, as previously moted, the success of this expedition casts aspersions about the much criticized Ensign Juan Perez.

Scholars averloak: Hezeta for ane very simple reason: the more significant achievements of the expedition cocurred after his ship and the vessel commanded by Bodega parted, tis turning southward and Bodega's continuing toward Alasta. Bodega, with the strong support of Mourelle, achieved the more substantive accomplishments of the expedition. Heaeta 
is historically important as the expedition leader, and for earning some modest successes after the ships parted. Df course, aften unstated in the literature is the inevitable comparison between the two vessels' captains.

Professor Donald C. Cutter raises two commonly made points with regard to the relative merits of the two ships" officers. First, he writes:

The intrepidness of these men cBodega and Mcurelle] is clearly demonstrated by the fact that the epic exploration was carried cut with a somewhat reduced and undertrained crew. 90

Not anly did the crew af the sonora suffer the cammon depredations of the sea--especially scurvy--but the men endured them in amounts nothing shart of considerably heroic proportions. When the vessel at length reached Monterey the crew was 50 ill that even Bodega and Mourelle had to be carried astiore!

In light of the ability and willingness an the part af Badega ta carry an despite sickness, Hezeta's decisian ta turn bact: pales. Writing for the majority, cutter notes that Hezeta "was not so daring as Mourelle and Eodega, but his acts of possessian were the basis for the Spanish claim to the area as far north as the state of Washington." ax In other words, where Perez failed completely to secure lands for the Crown, Hezeta achieved modest success. Badega, an

so Donald C. Cutter, "California, Training Ground for Spanish Naval Heroes," California Historical soojety Quarterly 40 (19E1): 110. 
the ottier hand, accomplistied as much, quite literally, as human endurance would bear.

Scholars view Bodega's passion for adventure as nothing short of rapacious. On this count, amateur historian Derel:

Petricl: presents the majority view using the courageous mariner's own wards:

...the command of it has been delivered to me, and I must act according ta the cade af honor corresponding to my birth... if fortune were 50 adverse that it gave me no assistance, then it is a glory for posterity when each man dies at his post for the king. ax

The best evidence for Bodega's courage and, conversely, the squeamishness of the afficers in the pilot ship (remember, Perez was Hezeta's second), can be found in the parting af the two vessels the night of July 31 . As alluded to in Chapter III, essentially two apinians exist for why the ships parted: it was planned; or, it was accidental. Scholars who believe that Bodega and Mourelle acted in a premeditated fastion, such as Cook and Thurman, are also more likely to vilify Ferez, and praise the former two mariners. Those wha label the parting accidental, ar are ambiguous about it, or those who mention nothing more than that the vessels parted and supply no especial reason for it, typically proffer a less harsh judgement of Perez (if judgmental at a11). These historians, such as Eolton and Bancroft, also are more restrained in their praise af Bodega and Mourelle. Other worts, such as Gough's, tend to be

$=$ Cited in Pethicl, First Approaches, 4.4. See alsa Elodega, $3-4$. 
incanclusive: he lashes out at Perez, as earlier nated, but says virtually nothing about tre 1775 and 1779 expeditions. The sum of the evidence points clearly to a negative evaluation of Perez.

Professar Chapman's treatment of the vayagers is a good case study af a disturbing pratfall that can trip the historian. First, he uses no relevant evidence to conclude that Perez was quite a success in his voyage north in 1774 , and he all but completely ignores the eclipsing of the ensign's meager accomplishments by Hezeta and Bodega as a measure of him. Further, he ignares the influence of Perez in canvincing Hezeta to turn southward (see chapter III. Last, and quite despite his immodest claim to be an very familiar terms with archival materials, Chapman ignores the very abvious primary evidence that others csee Thurman, Cool: and even Bancroft citing the opinions of Bucareli and Maurelle) demonstrate paints a rather unflattering portrait of the ensign. Ironically, standing in juxtaposition to the Perez detractars, Chapman's apparent lapses highlight the basic conclusions athers have come ta with regard to Perez, Hezeta and Bodega.

ARTEAGA AND EODEGA, 1779

If Hezeta is aften ignored in the literature, his notice is yet many times more evident than that of Arteaga, who led the last expedition to the narthwest coast during Bucareli"s tenure. While cartographically important, this 
expeditian, virtually all scholars agree, merits

considerably less stature than the earlier two. Perez is given some measure of praise far being first in the regian, breaking new ground, and, Hezeta-Eodega took the inmeasurably important possession at varicus places along the coast. However, with regard to the primary impetus behind the vayages, the Arteaga expeditian had little ground to breat:

Eancroft motes nothing more than its feat of mapping the coastline; Thurman's assessment af the expedition is similar; and, likewise, Chapman mentions only that the expediticn achieved a "careful exploration" of the Alaskan coast. The anly remately comprehensive treatment the expedition receives is from cool, who credits it with the mapping, and for having the unintended effect af inducing the Crown "to rest an its laurels," secure in the erroneous belief that the coast held little interest for ather European natians. For instilling a false sense af security in the Spanish court, Coor cites the expedition's failure ta discover evidence either af Captain James Caot:"s visit or of a Russian presence in the northern waters.

\section{ONE, TWO, THREE}

Without question the expedition of 1775 is seen as the most successful of the Eucareli years. To that end, its officers are accorded commensurate amounts of praise. Hezeta 
gets credit for, one, being the expedition leader and, two, for possession-taking on the Oregon and Washington coasts. Eodega and Mourelle reap the greatest praise because their contributions speak: af great intrepidness--certainly in the mold of the Conquistadores--and their possession-taking further north was of considerable geopolitical importance in Spain's estimation.

For same scholars Juan Perez deserves real credit far being the first to brave the northerly waters, to go where none had gone before. Yet for most historians this accomplishment merits little cause for distinction. Perez failed because he was timoraus, trey conclude, and not at all--much to his disgrace-maf the metal from which Badega and Mourelle were hewn.

Scholars consider Ignacio Arteaga to be of no especial importance, despite his cartograptical and possession-itaking achievements. He receives scant historical treatment largely because his accomplishments neither brake substantive new ground, nor represented any particular strategic gain.

In summation, then, scholars unequivocally rant: the intrepid Eodega and Mourelle well above their colleagues. The cautious yet persevering Hezeta represents an riancred second position. Arteaga occupies what might be best described as neutral, if not ambivalent, position-not unsuccessful, just ignored-near Hezeta. Perez sits quite alone and scorned in the distant last position. 


\section{CHAPTER $V$}

\section{CONCLUSIONS}

The expeditions sent north from San Blas during the tenure of Viceroy Eucareli have in part been overlactied as a discreet subject af inquiry because the story they tell has no sense of dramatic closure. That is, as is frequently the case with general histories, and as is certainly the case with the literature surrounding this paper's subject, written history appears to seets out an unambiguous ending to a tale. While it may be that if ane labks at the story of the three voyages af discovery--1774, 1775, and $1779--0 n e$ can identify a beginning, a middle, and an end, along with several heroes and at least one chump, the story fistory prefers is the one that closes with the spanish face-saving withdrawal from Nootka Saund in 1795. In that stary, the voyages discussed earlier in this paper provide the apening act.

Although almost 10 years of Spanish inactivity on the Northwest coast followed the Arteaga expedition, a renewed interest kindled in the late 1780's. The impetuses, again, generally resembled thase af the sixteenth century, thaugh fear of the British had grown exponentially. The result, most methodically presented by Professor warren coor, led, first, to the establishment of a Spanish settlement at 
Nootka Sound, ${ }^{*}$ and, second, to a confrontation in the 1790's between Spain and Britain, when the latter challenged the Spanist, claim. Spain, traditionally allied with France against Eritain, could count an na support fram its neighbor torn apart by revolutian. Unwilling to rist direct canflict with a more powerful adversary, Spain backed away from its claim to absolute sovereignty of the Pacific Northwest based an the Papal Eull of 1493 , the right of first discovery (Juan Perez), and the possessign-taking (Hezeta and Eadega, Et a 1 ).

The Nootla Sound controversy thus climaxed the story of Spain's interest in the Northwest. Conveniently, it fallows the traditional five-stage, Aristatilean course of narrative development: the "situation", is nothing more than the geopolitical cantext, a late eighteenth century Hobbesian world of competing interests; the "complication" is the mutually exclusive nature of the competing claims; the "crisis" arrives with the simple passage of time, i.e., at Nootra in the 1790"s; the "clima\%" accurs with negotiations to avoid war; and, the "denouement" completes the tale as spain withdraws. Whether or not historians have traditianally sought out suct sequences to identify as discreet historical

1 In particular, see Eartrali, Coak, Janes, Manning, and Derel: Pethick, The Nootka Connection, Eumope and the Northwest Pas5a9e, 1790-1795 CVancouver: Douglas i McIntyre, $1980 \%$.

- For a novel approach to the hammering out af the specifics of the settlement see Janet Fireman's article, - The Seduction of George Vancouver: A Nogtka Affair," Pacifio Historical Rewiew 5E (1987): 427-43. 
topics, ar whether they randamly impose such schematas atap events in itself represents a discreet subject; but far aur purposes it is clear from a representative sampling of the literature on the Spanish presence in the Pacific Northwest that such a linear trajectary lending itself to the Aristotilean development exists with regard to spain in the nirthiwest.

The causative agents engendering the expeditions during Bucareli's tenure remained consistent, if not constant. Equally important, yet touched an in none of the literature, the same can be said with regard to the late sixteenth-early seventeenth century voyages compared to their late eighteenth century counterparts. The lust for riches, far example, changed somewhat over two centuries in focus and intensity cdreams of a northern cibola existed anly unofficially). As reflected by the heroics of Eodega and Mourelle the will to adventure also continued ta inspire mariners; and the vilification af Perez emphasizes the point. Ultimately however, the quintessential, vainglorious Spanish concern entailed protection of territary that it held to be its awn; and spain's success has recessarily been measured by historians in these terms. That histarians have for the most part judged Perez, Hezeta, Ecodega, and Arteaga by the standards of their own era, then, denotes an essential fairness to the grades. In this respect, any similarity, whether warranted or not, between the grades and the "Great Men Male History", school should be seen as 
incidental, if not irrelevant. Yet there are problems with the appraach northwest scholars have followed.

To focus exiclusively on the Spanish calanial weltenschauung as the appropriate lens through which to view--and grade--the mariners obfuscates the important didactic role history can play, by isolating Spain without reference to the larger internatianal context. Moreover, it cloaks the past in unmerited romanticism, while essentially denying the realpolitit of the periad. Spain's desire to add one mare jewel-othe Pacific Northwest--ta her tarnished imperial crown iranically reflects the fundamental wealiness of its political system, and how that system had become thoroughly anachronistic for a would-be great power by the late eighteenti century.

Warren Coot: concludes The Flood Tide of Empire by arguing that Spain's attempt and subsequent failure to secure the northwest signaled the apigee of its imperial growth and expansion. $\Rightarrow$ This argument, while essentially correct, gecgraphically, is superficial, for it ignores all but the most abvious reason--Britain gutgunned Spain in Europe--that dowmed Spain's northwest caast venture to failure. Further, like other historians, Cook, by neglecting fully to acknowledge the lint between the impetuses behind the Eucareli-directed voyages and those of the late sixteenth-early seventeenth century expeditians, fails to 
distinguish the crucial point that Spain's imperial designs had been, since the inept reigns of the first Hapsburg manarctis, stymied for two fundamental socio-economic reasons, which ultimately portended Spain's imperial apogee and atrophy. First, Spain's autocratic-mercantile nature precluded effective exploitation af the Pacific Northwest. And, second, Spain's mon-Catholic European rivals--Britain, in particular-oproved to be far more able to explait economic gpportunities, in short, gut-campeting the Iberian nation.

Spain had made the mistake of assuming its New World economic successes accurred as the direct result of its method of canquest and exploitation. The accepted veracity af this erroneous notion grew in direct proportion to its longevity. The Rourbon Reforms, it should be recalled, aimed at improving a time-warn system, nat fundamentally altering it. The basic structure of government did not change in Spain after the Bourbon dynasty replaced the Hapsburg Iine, or in New Spain until the revolution for independence in the early nineteenth century. Spain's colonial profits were the ironic result of an approach that enjoyed success in New Spain, far the mast part, out of sheer coincidence.

Throughout the colonial period Spain basically sought bulliom from which it derived spiritual and economic sustenance, and found it aplenty in New Spain. The negligible effort required from the Spaniards, apart from establishing a way to exploit native labor, to extract the 
riches reinforced a distinctly non-capitalist cultural imperative. Moreaver, the positive correlatian between the methad employed and the results achieved the spanish confused for cause and effect. New World gold and silver thus fueled the empire economically and spiritually, and engendered the political will necessary for expansion.

That the expeditians discavered no conquerable or easily extractable supply of bullian on the northwest coast may or may not have influenced Spanish officials as to the regian's attractiveness, but the fundamental issue that the lust for bullion illustrates is that spaniards had not culturally developed, or adopted, another means by which to generate wealth. The Western warld had changed dramatically since Columbus invaded the Americas, but Spain continued to live in the past. The Russians for decades had exploited the sea otter trade in the north, but the Spanish, because af restricted mercantile policies--indeed, one might accurately say, mercantile mentality--neither had encouraged exploitation of the trade nor had prepared its citizens ta be able to identify and seize early capitalist opportunities.

Increasingly hapless, Spain's economic fortunes had been born of a mercantile system thoroughly ossified by the Jate eighteenth century. Britain, on the ather rand, adapted to and encouraged the creation of the emerging new warld ecomomic arder, capitalism. The Eucareli voyages--their rasion de*tete, and accomplishments--stoud in relation to 
foreign desjgns on the northwest coast as spain's moribund mercantile system staod in relatian ta emerging capitalism and Great Eritain: destined ta achieve less than ostensibly sought.

Warren Cogk: also argues that had Spain been more vociferous in staking its claims to the northwest littoral, it might have held the region. Eritain, he writes, found itself in mo position to hold the territary, as spanish firepower exceeded Eritish in the northeast Pacific. 4 But again, Cogl: averloots a cruclal aspect of the Eucareli vayages. The limited scape of the expeditians-a-a total af five vessels sailed--in part reflects the insufficiency af funds available for such ventures; but more importantly, the meager financing illustrated a general lact: of interest in Spain far the northwest caast af North America. The crown had an enormous empire to govern, and funds were necessarily allacated on a priority basis. Why had spain squandered twa centuries of potential discovery and accupation before deciding to return to the northwest coast in $1774 \%$ The answer is, for all the reasons heretofore discussed. To suggest that Spain could have defended the territory disingenucusly romanticizes and distorts the crown's intentions.

Viceroy Eucareli's rale in the vayages, while tis roughly nine years as secular regent of New Spain serve as traditianal perimeters to border this study, proved to be of 
little consequence. of his considerable merit as an administratar there is no daubt. of his role, ather than organizationally, in the expeditions there also is little daubt: a follower, albeit a very good one, the viceroy generated few original ideas. Visitadar Jose de Galvez deserves most af the individual credit for launching the expeditions, but such recogriction requires a caveat or runs the rist: committing a non-sequitur in the manner of chapman with Perez in California. Certainly, Galvez was the fey figure, but the genesis of his plans were only a manifest reflection of the zeitgeist of the Enlightenment, af which hie was a part and product.

Moreover, crowning Eucareli, or Galves, as "king of the Expeditions" would at best be an empty title. After all, Spain got nathing for their efforts: no bullian; no profit from the fur-trade; and, few native-American converts. Finally, as Barringtan explained the reasans for translating and publisting Mourel le's diary:

I was principally induced to take this trouble, because I supposed, that the spariards, from their most peculiar jealousy with regard to their American daminians, would never permit that navigators of ather countries (particularly the English) shauld know the excellent parts of the Western part of America.s

Deeply ironic, the Spanisti salvaged not even the glary af first discovery, which until. recently ajl tog often went to James Couti: 
EIEL IOGRAPHICAL. NOTE

Because the 1770's Spanist voyages of discavery and exploration have received no discreet, full-length airing, determining where the voyages sit with regard to accomplishment requires drawing evidence from a variety of saurces. The same sources have also been used as supporting documentation for this wart. There is no disingenuity in this: we are not interested in what happened so much as to understand why what happened is thought to be important or not important. First, there exists what for the purposes af this essay will referred to as the "regional" history, where our subject is addressed with varying emphasis as part of larger projects.

Bancroft provides good examples of the regional study in his histories of Califamia (1884), Alaska (188E), and af the Northwest Coast (18BE-8B), the latter being of the mast interest. These compretiensive, seminal worls necessarily examine figures such as Perez, Hezeta, Eodega, and Arteaga. Also in this group we can identify Charles Edward Chapman's oft cited and well documented histories of California 6913 and 1928). Jahn Caughey's history of California, althaugh differing sharply with Chapman on the causative agents behind the voyages, is an excellent, carefully prepared wort: (1940). Irving B. Richman's history of Califarnia represents 
a third general-regianal study af some interest (1965). Alan

C. Hutchinsan's study of the Califarnia frontier lends greater credence ta Caughey's mare complex presentation af the impetuses behind the vayages. Margaret A. Ormsby's textbogk, British Columbia: A History (1959), does not for the most part rely an primary sources far its informatian, and in this sense is mare typical of the northwest coast histories. This list is, of course, by no means exhaustive with regard to the body of historical literature of the several. regions--it is not meant to be-wrather, these worlis are important for this study because they al1 directly have offered opinions with regard to the voyages and their crews: Perez, Hezeta and Bodega, and Arteaga and Bodega have received greater or lesser amounts af scrutiny with varying conclusions reached.

A second body af material can be drawn from sources focused more directly to the "northwest coast" - -and will be so referred to-but range in specificity, and in their interest for our subject. This group includes the re-issue of Jahn Earrow's interesting examinatian af voyages to Arctic waters (1818). Henry Raup Wagner's exhaustive Cartography of the Northwest Coast (1997) provides a wealth af information, yet, as is typical of wagner's wort, is steeped in minutiae and provides little synthesis. The remaining works Tocus without exception an the Nogtha Sound controversy of the mid-1790'5. While W.R. Manning's 1904 report to the American Historical Assoriatior was published 
in periadical farm (the American Historioal Review, 1Gos) its comprehensive scope warrants notice here. Warren Cool:'s formidable 1973 Flood $T$ ide of Empire clearly stands as the definitive wort: in this field. The wort: of Thamas Vaughan Cas editor and contributing author, 1976), J. Arthur Lower (1978), Derel: Pethick (1976 and 1980), Earry M. Gough (1980), and Jahn kiendrict: (1986) provide standard and satisfactory treatments of the Eucareli-directed voyages. All rely more or less heavily on secondary sources. Four masters theses can also be included in this group: Mildred DeLonchamp (Adams State College, 1946), Tomas Eartroli CUniversity of Eritish Columbia, 1960), Dat:at, L. Janes (University of of:lahoma, 1960\%, and Herbert k. Beals (Portland State University, 1983). Additionally, selected periodical literature labors in similar, if less compretensive fastion: see William H. Galvani (1920), Lillian Estelle Fisher (1929), James G. Caster (1963), Clinton R. Edwards (1984), Christon l. Archer (1978-79), Eric: Beerman (1982), and Janet R. Fireman (1987). Again, as was the case with the regianal studies, this list does not exhaust all sources but it is representative of the salient conclusians reached with regard to the voyages discussed in this study.

Finaly, a last distinguishatble group deals with the voyages in a "peripheraj" way, as part of discreet inquiries tangentially related to gur subject. These include works whose focuses lie elsewhere but find a discussian of 
the voyages indispensable to their topics. They include the anguished prose of Herbert Ingram Priestley's atterwise commendable 131E biggrapty of Jose de Galvez. The seminal American borderlands historian Herbert Eugene Haltan's 1927 study of Fray Juan Crespi is also instructive. Alfred Earnaby Thomas only briefly notes the northwest explorers in His Teodoro de Croix and the Northern Frontier of New Spain (1941). Eerrard E. Eobb's 19E2 biograpty af Antonio Bucareli is a mature, well. researctied labor of love, and an invaluable source. The exemplary 1967 study of the Naval Station at San Blas by Michael E. Thurman examines the voyages and their captains in some detail. Finally, Robin Fisher touches on the expeditions in a 1977 study af the early years of Britist, Columbia. 


\section{REFERENCES}

\section{PUEL. ISHED DOCUMENTS}

Beals, Herbert k., trans. For Homor and Country, The Diary of Brung de Hezeta. Portland: Dregon Histarical Saciety Press, 1985.

Eodega y Quadra, Juan Francisca de la. Typescript. Expeditions in the lears 1775 and 1779 towards the Northrest Coast of North Ameriea. Victoria, B.C.: Eritish Columbia Pravincial Archives, 1912. Trans. G.F Earwict:, 1912 .

Campa Cos, Fray Miquel de la. A Joumnal of Explorations: Northward Along the Coast From honterey in 1775. Trans., Ed. Jotin Galvin. San Francisco: Jatin Howell, 1964.

Crespi, Juan, diaries of in FrayJuan Crespi, Missionamy Explorer on the Pacific Coast, 1759-1774, by Herbert Eugene Balton. 1927. New Yort: AMS Press, 1971.

Cutter, Donald C., ed. The C.aI ifornia Coast: A BilinguaI Edition of Document.s from the sutmo collection. Ed. Donald C. Cutter, and Gearge Eutler. Narman: University of oll latioma Press, 1969.

Fulunte, Jose de la. "Diary of Fedro Jose de la Fuente, Captain of the Presidio of EJ. Paso ded. Norte, August December, 17E5." Trans., Ed. James M. Daniel. Southwestern Historical Guarterly 83 (1979-80): 259-78.

Galvez, Jase de. Instructions for Governing the Interior Provinges, 1786. Ed. Donald E. Worcester. Berleley, 1951.

Eassner, Julius S., trans., ed. Voyages and Aduentures of la

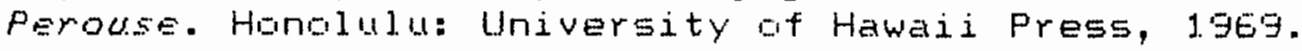

Humboldt, Alexander van. Political Essay on the kingoom of Now Spain. Zvuls. New Yorti, 1811.

Iamesan, J. Frantilin, gen. ed. Early Narratidss of the Northwest. 153t-1599. Ed. Louise Phelps Kellogg. 1917 New Yort: Barnes \& Noble, Inc., 1967. 
Jane, Cecil, trans. A Spanjsh Voyage to Vancouver and the Northwest Coast of America. 1930. New Yorl: AMS Press, 1971 .

kimnaird, Lawrence, trans., ed. The Frontiems of New Spajn, Nicolas de Ia Fora s Deseription, 1750-1758. 1958. New Yort: Arno Press, $19 \in 7$.

Mourelle, Francisco Antonia. "Journal of a Vayage in 1775." In Hiscellanies, Voyage of the sonora in the Second Bucareli Administration to Explore the Northwest. Coast...177s. 1781. Trans. Daines Barrington, 1920.

Mozing, Jose Mariano. Notiajas de Nutka. An Acoount of Nootka sound in 17gz. Trans., Ed. Iris Higbie Wilson. Seattle and London: University of Wastington Press, 1970 .

Servin, Manuel. P. trans. "The Instructians af Viceroy Bucareli to Ensign Juan Perez." California Historical Society Quarterly 40 (1961): $237-48$.

Wagner, Henry R. "Fray Benito de la Sierra"s Account af the Hezeta Expedition to the Northwest Coast in 1775.', Trans. A. J. Batier. California Historical Society Quarterly 9 (1930): $201-42$.

\section{UNPUBL ISHED THESES}

Eartroli, Tomas. "The Spanish Establishment at Nactia Saund (1789-1792)." Masters Thesis. Vancuuver: University of Eritist, Columbia, 1960 .

Eeals, Herbert K. "The Introductian af Cultural Materials an the Narthwest Caast Befare 1800." Masters Thesjs. Partland: Partland State University, 1983.

DeLongchamp, Mildred k. "Explarations to the Northwest Coast of America Eefore 1800." Masters Thesis. Alamosa: Adams State College, 1946.

Jones, Oakah L. "The Spanish Occupation of Nootlia Sound, 1790-1795." Masters Thesis. Norman: University at Dit latioma, 1960 .

\section{SECONDARY MATEF.IALS}

Bancraft, Herbert Howe. History of Alaska, 1730-1885. XXXIII. San Francisco, 1886. 
-.-, History of the Northwest Coast. XXVII. San Francisco, $18 B E-8 B$.

--, History of the North Mexican States and Texas, 15311800. XV. San Francisca, 1886.

--- History of California, 1542-1800. XVIII. San Francisco, 1884.

Eannon, Jotin Francis. Herbert Eugene Eolton. The Historian and the Man, 1970-1953. Tucson: University of Arizona Press, 1978.

Earrow, John. A Chronologiad Sumwey of Voyages into the Arotic Regions. 1818. New Yorl: Barnes and Noble, 1971.

Eabb, Eernard E. The Viceregenoy of Antonio Maria Eucareli in New Spain, 1771-177s. Austin: University af Texas Press, 1962 .

Bajtan, Herbert Eugene. Fray Juan Crespi: Missionary Explorer on the Pacific Coast. 1769-177\%. 1927. New Yarl:: AMS Press, 1971.

Eraden, Charles S. ReIigious Aspects of the Conquest of Mexico. Durtiam: Dute University Press, 1930.

Caughey, John W. Hubsmt Howe Eanamoft. Histomian of the Hest. Eerleley: University af Califarnia Press, 1946.

-.-, California. New Yort: Prentice Hall, Inc., 1940.

Chapman, Charles Edward. The Founding of Spanish Califomnia, The Narthwestwand Expansian of New Spajn, 1687-1783. 1913. New Yark: Octagon Boaks, 1973.

-... A History of Califormia: The 5panish Pemiod. New Yart: The MacMillan Co., 1928.

Cleland, Robert Glass. From Hilderness to Empire: A History of California. New Yort: Alfred A. Knopf, 1959.

Cioli, Warren E. Flood Tide of Empire, Spain and the Pacifia Northwesty 1543-1819. New Haven: Yale University Press, 1973.

Cutter, Donald C. "The Western Spanisti Borderlands,', Historians and the American Mest. Ed. Michael. P. Malane. Lincoln: University of Nebrasta Press, 1983.

Fistier, Lillian Estelle. The Intendant system in spanjsh America. New Yort: Gordian Press, 1969. 
--., Viceregal Administration in the spanish-American

Colonies. Berteley: University of Califarnia Press, 1926.

Fisher, Raymond H. Bering's Voyages, Whither and Why. Seattle: University of Washington Press, 1977.

Fisher, Rabin. Contact and Confliat, Indian-Eumopean ReIations in British Columbia, 1774-1890. Vancouver: University of British Columbia Press, 1977.

Gerhard, Peter. Pirates on the West Coast of New Spajn, $1575-1742$. Glendale: Arthur H. Clart: Company, 1960.

Gough, Barry M. Distant. Dominjon, Eritain and the Northrest Coast of North Amerisa, 1579-1809. Vancouver, University of British Columbia Press, 1980.

Hante, Lewis. Aristotle and the Indians. Chicaga: Henry Regnery Company, 1359.

Harqraves-Mawdsley, W.N. Spain Under the Eourbons, 17001833: A Collection of Documents. London: The MacMillan Press Ltd., 1973.

Haring, Clarence Henry. The Spanish Empire in timerica. New Yort: Harcourt, Brace \& World Inc., 1947.

Harjow, V.T. The Founding of the second Eritish Empire, $1763-1793.2$ vols. Landon: Langmans, Green, $1 \exists E 4$.

Herr, Richard. The Ejghteenth-Century Revolution in spain. Frincetan: University Press, 1958.

Holmes, Maurice G. From New Spain by Sea to the Californias. 1519-1568. Glendale, Ca.: The Arthur H. Clarke Ca., $19 E 3$.

Horgan, Paul. Conquistadors in North American History. New Yart: Farrar, Straus and Company, 1963.

Hull, Anthany E. Charles III and the Revjual of spain. Washington: University Press of America, 1981.

Hutchinson, Alan C. Frontier Settlement jn Mexican

California. New Haven: Yale University Press, $196 \exists$.

Ireland, Gordon. Boundaries, Possessions, and Conflicts in Central and North America and the Caribbean. Cambridge: Harvard University Press, 1941.

keen, Eenjamin, ed. Readings in Latin American Civilization, 1492 to the Present. Bostan: Houghton Miffin Lo. 1955 . 
kendrict, Jatin. The Men with Wooden fest, The Spanish

Exploration of the Paeific Northwest. Toronto: NC Press Ltd., 1986 .

Leanard, Irving A. Earoque Times in Old Mexico. Ann Arbar: University of Michigan Press, 1953.

---, Books of the Erave. Cambridge: Harvard University Press, 1949.

Liss, Peggy. Mexico Under spain, 1521-1556, sosiety and the Origins of Nationality. Chicago: University of Chicago Press, 1975 .

Lovett, A.W. Early Hapsburg Spajn, 1517-159g. Oxfard: Oxfai University Press, 1986.

Lower, J. Arthur. Doean of Destinys A Consise History of the Nonthemp Pacific, 1500-1978. Vancouver: University of Eritish, Columbia Press, 1978.

Lynct, Jatin. Spain Under the Hapsburgs. Oxford: Easil Elackwe11, 1969 .

McDonald, Lucile. Searoh for the Northwest Passage. Portland: Einfords and Mort, 1958.

Madariaga, Salvador de. The FaIl of the Spanish American Empire. New Yort: MacMillan Co., 1948.

--., The Pise of the Spanish American Empine. New Yart: MacMilian Co., 1947.

Nunn, Gearge M. Origin of the Strait of Anian Consept. Priladelptia: n.p., 1929.

Ormsby, Margaret A. Eritish CoIumbia: A History. Taranta: MacMillan, 1958.

Pethict, Derel. First Approadhes to the Northwest Coast. Vancouver: J.J. Douglas Ltd., 1976.

-.., The Nootka Connection, Eumope and the Northwest. Passage, 1790-1795. Vancauver: Dauglas \& McIntyre, 1980 .

Petrie, Charles. King ChamIes III of Spain. An EnIightened Despot. London: Constable \& Co., 1971.

-- Philif II or Spain. London: Eyre \& Spottisworde, 1963. 
Priestley, Herbert Ingram. Josede Galvez, Uisitor-GeneraI of Now Spain (17G5-17T1). Eerlieley: University of California Press, 1916.

Richman, Irving E. Caljfornia Under Spajn and Mexico, 15351847. New Yarl: Cooper Square Publishers, Inc., 1965.

Saavedra, Santiago, gen. ed. Gabriela Eernar, Rufino Diaz, Victoria Lasso, and Juan Perez, eds. To the Totem Shore: The Spanish Presence on the Northwest Coast. Madrid: Ministerio de Turisma y Transporte, 1986.

Schurz, William Lytle. The Manila Galleon. New Yark: E.P Dutton \& Ca., Ine., 1939.

Simpson, Lesley Eyrd. The Encomienda in New Spain. Eertieley: University of California Press, 1950.

---, Many Mexicos. Eerteley, Los Angeles: University uf California Press, 1941.

Smith, Donajd E. The Vigeroy of Naw Spain. Eerteley: University of California Press, 1913.

Thumas, Alfred Barnaby. Teodoro de Crojx and the Northern Frontier of New Spain, 1776-1783. Norman: University of Orilatioma Press, 1941 .

Thurman, Michael. E. The Naval Department at San Elas, NeN Spain"s Lastion for Alta California and Nootka, 1767 to 179g. Glendale, Ca.: The Arthur H. Clart:e Co., 1967.

Vaughan, Thomas, ed. The Western Shore. Portland: Oregon Histarical Saciety, 197E.

Wagner, Henry R. The Cartography of the Northwest Coast of fimerisa to the rear 1800. 2 vols. Eertieley, 1937.

--., Spanish Voyages to the Northwest aoast of Amerisa in the Sixteenth Century. San Francisco: California Historical Society, 1929.

-., Sir Francis Drake"s Voyage Amound the Womld: Its Ajms and Achievements. San Francisca: Jahn Howell, 1926.

PERIODICAL LITERATURE

Aiton, A.S. "Spanish Colonial Regrganization Under tre Family Compact." Hispanio Amerioan Historical Review $11-12(1931-32): 269-80$. 
Anna, Timathy E. "Spain and the Breakdawn of the Imperial Ethos: The Problem of Equality.' Hispanje Amemican Historical REVIEW EZ (1982): 254-272.

Archer, Christon I. 'Bourbon Finances and Military Policy in New Spain, 175g-1812." The Americas 37 (1980-81): $315-50$.

-- "Retreat from the North: Spain's Withdrawal from Nogtla Sound, 1793-1795." E.C. Studies 37-38 (197879): $19-36$.

-..., "To Serve the king: Military Recruitment in Late Colonial Mexico." Hispanis Amemiadn Historial Foujew $55(1975): 227-250$.

Barbier, Jacques. "The Culmination of the Ecurbon Reforms, 1787-1792." Hispanja Ameriaan Historical Raview 57 $(1977): 51-68$.

Bauer, Arnold J. "The Church in the Ecanomy af Spanish America: Censos and Depositos in the Eighteenth and Nimeteenth Centuries.' Hispanic American Historical REUIEW E3 (1983): 707-733.

Eeerman, Eric. "Basque Sailgr at Bucareli Bay." AIagka Journal 12 (1982): 44-51.

Boyer, Richard. Mexico in the Seventeenth Century: Transitian of a Colonial Society." Hispanic American Historical Reyiew 57 (1977): 455-503.

Brasseaux, Carl A., ario Richard E. Chandler. "The Eritain Incident, 1769-1770: Angla-Hispanic Tensians in the Western GuIf." Southwestern Historical Quarterly 87 $(1983-84): 357-70$.

Eurt:tolder, Mart: A. "The Council of the Indies in the Late Eighteenth Century: A New Perspective." Hispanja American Historical ReView $5 E$ (197e): 404-423.

-.-., and D.S. Chandler. "Creole Appointments and the Sale af Audencia Positions in the Spanish Empire under the Early Eluubans, 1701-1750." Joumnal of Latin Ameriaan studies $3-4(1971-72): 187-206$.

Caster, James G. "The Last Days of Juan Ferea, The Mallorcan Mariner." Joumbal of the Hest 2 (1963): 1521 .

Christelow, Allan. "Great Eritain and the Trades from Cadiz and Lisbon to Spanish Americe and Brazil, 1759-1783.'" Hispanio American Histomical Revisw 27 (1947): 1-29. 
Cuel.10, Jase. "The Economic Impact of the Bourbon Reforms and the Late Colonial Crisis af Empire at the Local Level." The Americas 44 (1987-88): $301-23$.

Cutter, Danald C. "Califarnia, Training Grourd for Spanish Naval Heroes." Cal ifomia Historical society Quarterly 40 (19E1): $109-22$.

Edwards, Clinton R. "Wandering Toponyms: El Puerto de la Eodega and Eudega Eay.' Paojifo Historical Review 33 $(1964)=253-72$

Engstrand, Iris. "The Enlightenment in Spain: Influences Upan New Warld Policy." The Americas 41. (1984-85): $43 E-444$.

Fireman, Janet R. "The Seduction of George Vancouver: A Noutla Afrair." Paoifio Historial Reviow SE (1987): $427-43$.

Fisher, Lillian Estelle. 'Teodara de Craix.' Hispania American Historical Rewjew G (1929): 489-504.

Galvani, William H. "The Early Explaratians and the Origin of the Name of the Oregon Country." Oregon Historical Quarterly 21 (1920): $332-340$.

Hennessey-Cummins, Victoria. "Imperial Policy and Church Income: The Sixteenth Century Mexican Church." The Americas 43 (1986-87): 87-103.

Howay, F.W. "The Spanish Settlement at NoGtha. "Washington Historical Quarterly $8-9$ (1917-18): $1 E \Xi-71$.

Kelsey, Harry. "Mapping the Califurnia Caast: The Vayages af Discovery, 1533-1543.' Arizona and the WEst $2 E$ $(1984): 307-24$.

Kirty, Dianne. "Colonial Policy and Native Depopulation in California and New Suuth Wales, $1770-1840 .$,

Ethnohistory 31 (1984): 1 - 1 .

Leon-Portilla, Miguel. "California in the Dreams of Galvez and the Achievements of Serra." Americas 41 (1984-BS): $428-34$.

Lewis, Erenda R. "North American El Darado." Amariaan History IIIUstrated 17 (1982-83): 10-19.

McNeil, william H. Mythtistory, ar Truth, Myth, Histary, and Historians." Presiciential Address to the American Historical Assaciation. Printed in the American Historical Reujes 91 (198E): 1-11. 
Manning, W.R. "The Noutla Sound Contraversy." American Historical Society Annual Repomt 1904 (1905): 279-478.

Nast, Gerald D. "Califarnia and Its Histarians: An Appraisal of the Histaries af the State." Pacific Histomical ReUien 50 (1981): $387-97$.

Ggden, Adele. "The Califarnias in Spain's Pacific Dtter Trade, 1775-1795." Pacific Historical Review 1 (1932): $444-69$.

Rahn Prillips, Carla. "Time and Duration: A Model for the Economy of Early Modern Spain." American Historical Revien $92(1987)$ : $531-62$.

Riclard, T.A. 'The Strait Gf Anian.' British Columbia Historical Quarterly $5(1941): 1 E 1-84$.

Sanchez, Jaseph P. "Pedra de Alberni and the Spanish Claim at Nogtla, The Catalonian Volunteers on the Northwest Coast." Pacific Northwest Quarteriy 70-71 (1979-80): $72-77$.

Servin, Manuel. "Religiaus Aspects of Symbolic Acts of Sovereignty." The Americas 13 (1957): 255-E7.

Stafford Poule, C.M. "Church Law and the Ordination of Indians and Castas in New Spain." Hispanic American Historiad RaviEN E1 (1981): E37-E5O.

Stein, Stanley J. "Bureaucracy and Eusiness in the Spanish Empire, 1759-1804: Failure af a Bourbon Reform in Mexica and Peru." Hispanis American Historiall Review $61(1981): 2-28$.

Tomplins, Stuart R. and Max L. Mourhead. 'Russia's Apprgach to America." Eritisth Columbia Historical Guarterly 13 $(1949)$ : $55-E E$.

Van Alstyne, Richard W. "International Rivalries in Pacific Northwest." Oregon Historioal Quarterly 4E (1945): $185-218$.

Wagner, Henry R. "Creation af Sovereignty through Symbalic Acts." Pacifio Histomial Revisw 7 (1938): 297-327.

Woodcoct, George. "Captain Cogt: at Nootta: The Political Aftermath." History Today 2B (1978): 97-104. 